NBER WORKING PAPER SERIES

\title{
HOME CARE REIMBURSEMENT, LONG-TERM CARE UTILIZATION, AND HEALTH OUTCOMES
}

\author{
Robin McKnight \\ Working Paper 10414 \\ http://www.nber.org/papers/w10414 \\ NATIONAL BUREAU OF ECONOMIC RESEARCH \\ 1050 Massachusetts Avenue \\ Cambridge, MA 02138 \\ April 2004
}

I am grateful for the guidance of Jon Gruber, Jim Poterba and David Autor and for helpful discussions with Daron Acemoglu, Emek Basker, Tom Davidoff, Peter Diamond, Amy Finkelstein, Chris Hansen, Patricia Keenan, Cindy Perry, Jon Reuter, Larry Singell, Wes Wilson and seminar participants at Amherst College, CBO, UC-Davis, the Federal Reserve Board, Harvard School of Public Health, MIT, RAND, Texas A\&M's Bush School, and the University of Oregon. Funding from the National Institute on Aging, through Grant \#K12-AG00983 to the National Bureau of Economic Research, is gratefully acknowledged.The views expressed herein are those of the author(s) and not necessarily those of the National Bureau of Economic Research.

C2004 by Robin McKnight. All rights reserved. Short sections of text, not to exceed two paragraphs, may be quoted without explicit permission provided that full credit, including $(\mathrm{C}$ notice, is given to the source. 
Home Care Reimbursement, Long-term Care Utilization, and Health Outcomes

Robin McKnight

NBER Working Paper No. 10414

April 2004

JEL No. I1

\title{
$\underline{\text { ABSTRACT }}$
}

Long-term care currently comprises almost $10 \%$ of national health expenditures and is projected to rise rapidly over coming decades. A key, and relatively poorly understood, element of long-term care is home health care. I use a substantial change in Medicare reimbursement policy, which took the form of tightly binding average per-patient reimbursement caps, to address several questions about the market for home care. I find that the reimbursement change was associated with a large drop in the provision of home care. This drop was concentrated among unhealthy beneficiaries, which is consistent with the incentives for patient selection inherent in the per-patient caps. I find that the decline in home health utilization was not offset by increases in institutional long-term care or other medical care and that there were no associated adverse health consequences. However, approximately one-quarter of the decline in Medicare spending was offset by increases in out-ofpocket expenditures for home health care, with the offset concentrated in higher income populations. Despite the value of home health care implied by the out-of-pocket expenditures, I find that the welfare implications of the reimbursement change were ambiguous.

\author{
Robin McKnight \\ Economics, 435 PLC \\ 1285 University of Oregon \\ Eugene, OR 97405 \\ and NBER \\ robinm@uoregon.edu
}




\section{Introduction}

Long-term care is a policy issue of growing importance in the United States. In 2000, combined home- and community-based care and nursing home costs for the elderly totaled $\$ 98$ billion, with Medicare and Medicaid bearing 56\% of these costs (U.S. Congress 2000). This spending level corresponds to roughly $10 \%$ of national health expenditures and $1 \%$ of GDP. Moreover, demand for long-term care is expected to increase dramatically over the coming decades due to the aging of the population. Estimates suggest that the number of elderly people requiring assistance with activities of daily living will increase by $42 \%$ between 2000 and 2020 (U.S. Congress 2000). Many of these elderly people will require long-term care, in the form of nursing home care or home health care.

Traditionally, long-term care was synonymous with institutional care at nursing homes. In 1980, expenditures for institutional care were seven times greater than expenditures for home health care (HHS 2002). But the past two decades have seen a radical shift in the composition of long-term care spending. Nursing home usage has fallen substantially; between 1985 and 1995, there was an $8.2 \%$ decline in the share of elderly who reported staying overnight in a nursing facility on a given day (Bishop 1999). And there has been a parallel substantial rise in long-term care delivered in the home setting, "home health care", over the same period, with an $82 \%$ increase in the share of Medicare beneficiaries who used home care and a $208 \%$ increase in the number of home care visits per user (U.S. Congress 2000). As a result, by 1995, expenditures for nursing home care were only twice as great as expenditures for home care (HHS 2002).

This dramatic shift in the composition of spending on long-term care naturally leads to several important questions. First, was the increased use of home health care during this period causally related to the reduction in nursing home use? Second, given the lower costs associated 
with providing home care, did the increased use of home health care reduce overall expenditures on long-term care? Finally, what was the impact of increased home care utilization on the health status of the elderly?

This paper addresses these questions using evidence from a policy change that caused a dramatic reversal of home care utilization growth rates. Specifically, I examine the short-run impact of a substantial change to Medicare reimbursement for home care in October 1997. The policy change had dramatic aggregate effects, causing an immediate 30\% decline in Medicare expenditures for home care.

The reimbursement change, which involved the imposition of average per-patient reimbursement caps, also fundamentally changed the incentives faced by home care agencies. By shifting from fee-for-service to a more prospective reimbursement system, Medicare's home care program encountered a trade-off between incentives for patient selection and incentives for efficiency in the production of medical care (Newhouse (1996)). In this paper, I model a profitmaximizing home health agency with two patient types -- long-term and short-term. The model shows that the imposition of an average per-patient cap on Medicare reimbursement can lead the agency to intentionally shift the composition of its patients towards short-term patients and to provide a lower intensity of care to its long-term patients.

The empirical analysis uses data from the 1992-1999 Medicare Current Beneficiary Survey (MCBS) to examine whether the imposition of average per-patient caps shifted the composition of home care utilization and affected health status and use of other types of care. To identify effects of the reimbursement change, I utilize state variation in the restrictiveness of the per-patient caps. In particular, caps were constructed as a weighted average of the historical costs per home care user in each agency and the mean historical costs per home care user in each 
agency's Census division. In consequence, agencies with otherwise similar utilization patterns faced differential incentives across states to cut back on per-patient costs after the Medicare reimbursement policy change. For example, aggregate data suggests that agencies in Georgia and Oklahoma provided similar average amounts of care to their users in the pre-policy years, but agencies in Georgia faced more stringent per-patient caps than those in Oklahoma, due to the regional component of the per-patient cap calculation.

Using this identification strategy, I find significant declines in the utilization of home health care in the post-policy period, consistent with aggregate data. Strikingly, I find that these declines were driven exclusively by declines in use among the beneficiaries who appeared likely to incur the highest home care costs. Relatively healthy beneficiaries experienced an insignificant increase in home care usage, whereas relatively unhealthy beneficiaries experienced a significant decline. These findings are consistent with the model's prediction that agencies would respond to the reimbursement change by favoring relatively healthy, low-cost patients.

A subsequent analysis examines how changes in the cap and the consequent use of home health care affected utilization of other types of care, providing evidence on the substitutability of home care for nursing home and other types of care. I find no evidence that the policyinduced reduction in home health care increased the likelihood of receiving long-term facility care. I also find little evidence of increased expenditures for other types of care, although my estimates are somewhat imprecise. Moreover, I find no evidence that this reduction in home health care utilization had an adverse impact on the health of the elderly.

One possible explanation for these findings is that individuals offset the cuts in financing for public home health care visits by increasing their own out-of-pocket spending on home health 
care. I find evidence that roughly $22 \%$ of the decline in Medicare home health care spending was offset by increased out-of-pocket spending. Increases in out-of-pocket spending were concentrated among relatively high-income beneficiaries but, even among those low-income beneficiaries who did not offset the cuts, there was no offsetting increase in other health care spending and no adverse impact on health.

Finally, the fact that individuals desired to offset some of these public spending cuts suggests that they were partially valued on the margin. I therefore discuss the welfare consequences of this policy change, but conclude that the net effect on welfare was ambiguous.

\section{Background}

Home health care is medical care that is provided in the home of the patient. To qualify for Medicare coverage of home health care, a beneficiary must be home-bound, under the care of a physician and require part-time or intermittent skilled care. The early 1990s witnessed unprecedented growth in Medicare expenditures for home health care, with expenditures increasing from $\$ 3.4$ billion in 1989 to $\$ 19.2$ billion in 1996 . $^{1}$ During this time, the percentage of beneficiaries who used home care almost doubled - from 5.1\% to $9.5 \%$ - and the number of visits per user almost tripled-from 27 to 79 (U.S. Congress 2000). This growth was precipitated by a liberalization of the Medicare home care benefit rules, following the settlement of a class action lawsuit in 1988. Newhouse (2002) argues that this growth also reflects increased use of post-acute care as a substitute for the last days of a hospital stay, in response to Medicare's prospective payment system (PPS) for hospital care.

In response to rapidly rising expenditures, Congress mandated the development of a PPS for home care in the Balanced Budget Act of 1997 (BBA 97). In order to slow the growth of

\footnotetext{
${ }^{1}$ Dollar amounts, throughout the paper, are in real (1999) dollars
} 
home health expenditures in the interim before the PPS was ready to be implemented, BBA 97 also created an "Interim Payment System" (IPS) that took effect in October 1997. At the same time, Congress mandated PPS for Medicare reimbursement of other forms of post-acute care, including short-term skilled nursing facilities (SNFs) and rehabilitation services, but the IPS was the first policy to take effect.

Prior to BBA 97, home care agencies were reimbursed for their "reasonable" costs, subject to a per-visit cap. The per-visit cap, which was equal to $112 \%$ of the national average cost for each type of visit, was applied to aggregate agency payments. This reimbursement policy was considered inadequate, because agencies had no incentive to minimize the number of visits provided to each patient. Furthermore, there were no financial constraints on demand, because beneficiaries face no cost-sharing for home care.

Beginning in October 1997, the IPS added an additional limit to the calculation of agency reimbursements: an annual per-patient cap. This new, agency-specific cap was calculated as a weighted average of each agency's 1994 average per-patient costs and the 1994 regional average per-patient costs. The agency's own average per-patient costs comprised $75 \%$ of the cap, with the regional average per-patient costs comprising the remaining $25 \%{ }^{2}$ Thus, those agencies that had above-average per-patient costs within their region in 1994 received per-patient caps that were lower than their 1994 per-patient costs; agencies that had below-average per-patient costs in 1994 received caps that were higher than their 1994 per-patient costs. In a regulatory impact statement in March 1998, HCFA projected that $58 \%$ of agencies would exceed the per-patient cap; by the following year, this projection was raised to $79 \%$ (Federal Register 1998, 1999).

\footnotetext{
2 "New" agencies, for whom 1994 reimbursement information was not available, received a cap equal to the national median cap, adjusted for regional differences in labor costs. In response to complaints that this formula led to new agencies in some areas receiving more generous caps than old agencies, 1999 caps for "old" agencies with caps below the national median were increased. The increase was equal to one-third of the difference between the agency's baseline cap and the cap for new agencies.
} 
Newhouse (1996) shows that prospective reimbursement, such as the IPS, yields two distinct incentives for health care providers: (1) a production efficiency incentive arising from the fact that providers can keep any residual reimbursement; and (2) a selection incentive arising from the fact that lump-sum payment transfers the risk of high costs to the provider. Newhouse reviews the empirical evidence on this issue, which generally supports the theoretical prediction that providers and insurers respond to capitated payments by selecting the healthiest patients. It follows that full prospectivity is unlikely to be optimal, due to the welfare loss from increased patient selection.

Empirical evidence about the response of home health agencies to a transition from feefor-service to prospective reimbursement is available from an experiment in the early 1990s. Cheh (2001) evaluates the impact of the experimental PPS on patient selection, health care utilization and health outcomes. She finds strong evidence of declines in home care utilization, but little evidence of patient selection, adverse health effects, or increased utilization of other forms of care. However, there are several reasons that these conclusions may not generalize to the situation of BBA 97. First, important features of the experimental PPS-notably, the use of adjustments for agency case-mix — were not used in the IPS. Second, agencies participated voluntarily in the experiment and were insured against $97-99 \%$ of any losses that were generated as a result of the experimental PPS. In contrast, the IPS was mandatory and did not offer any insurance against agency losses. As a result, agencies may have reacted more strongly to the IPS than they did to the experimental PPS.

In January 1998, CBO projected that BBA 97 would lead to a slowing of the growth rate of Medicare's home care expenditures (CBO 1997). However, as Figure 1 shows, home health expenditures actually plummeted by almost $\$ 6$ billion in 1998 . Figures 2 and 3 show that both 
the dramatic pre-1997 increase in expenditures and the striking post-1997 decline in expenditures were driven primarily by changes in the number of visits per beneficiary, rather than changes in costs per visit. Data from the Health Care Financing Review's annual statistical supplement indicate that the striking decline in visits per beneficiary reflects substantial decreases in both the share of beneficiaries who used home care (an 11\% decline between 1996 and 1998) and in the number of visits per user (a 31\% decline between 1996 and 1998).

Some observers have complained that declines in home care led to increases in the utilization of other forms of health care. ${ }^{3}$ Indeed, it is plausible that Medicare could lose money by cutting back on home care reimbursement if, for example, the policy change led patients to substitute relatively expensive inpatient care for less expensive home care. Alternatively, Medicaid or individual patients could bear financial costs if patients moved from home care to nursing homes.

The issue of substitution between home care and other forms of care has long been a question of interest to health economists. In the early 1980s, the National Long Term Care Demonstration project was implemented, providing case management and community services to a treatment group. Kemper (1988) summarizes the conclusions of the evaluation. He reports that patients and informal care-givers in the treatment group were more satisfied with the care and quality of life; however, the additional services led to higher net costs because there were no offsetting decreases in the costs of other care, notably nursing home care. The findings of other, smaller demonstrations have suggested that there may be some opportunities for home care to

\footnotetext{
${ }^{3}$ For instance, a hospital administrator told the New York Times, "Our hospital has been busier since the cutbacks in home health care. We attribute quite a bit of that to the fact that we can't provide adequate home care. Patients are admitted or readmitted to the hospital or to a nursing home, and both of those are more expensive than home care" (Pear 2000).
} 
substitute for other care, especially if increases in home care usage are well-targeted. ${ }^{4}$ However, in the 20 years since these experiments, many aspects of the health care system - such as hospital reimbursement - have changed in ways that are likely to have impacted home care utilization patterns. This paper provides updated evidence that is more relevant in the current health care environment.

Hadley et al. (2000) consider the relationship between post-acute Medicare home health care and health status in the early 1990s. They rely on year effects and regional market characteristics to identify the impact of home health care and find a positive effect. Their research, however, focuses only on a subset of home health users and is therefore not generalizable to the case of the IPS.

\section{Theoretical Framework}

The intention behind the IPS legislation was to provide an incentive for agencies to provide care efficiently. Lawmakers intended that "payments on behalf of patients whose costs were lower than average would 'subsidize' more costly patients; the balance of low and high cost patients would determine whether an agency would exceed its aggregate per beneficiary cap” (U.S. Congress 2000). However, a simple model, evaluated under reasonable assumptions, suggests that the IPS also introduced an incentive for agencies to favor patients who appeared likely to incur low costs.

\footnotetext{
${ }^{4}$ Hughes, Susan, Larry Manheim, Perry Edelman, and Kendon Conrad (1987). Kemper (1988) cites additional evidence from Blackman, D. et al (1985). South Carolina Community Long Term Care Project: Report of Findings. Spartanburg: South Carolina State Health and Human Services Commission.
} 


\section{Pre-policy}

Suppose there are two types of patients, those with short-term needs, type $S$, and those with long-term needs, type $L$. An agency chooses the number of short-term patients to treat, $N_{S}$, and the number of long-term patients to treat, $N_{L}$, to maximize its profits. Under pre-policy reimbursement, the agency receives reimbursement, $P$, for each unit of care intensity provided to either type of patient. $P$ is fixed at Medicare's per-visit cap for each visit. I initially assume that the level of care intensity, $I_{i}$, is fixed for each type of patient. It is convenient to think of $I_{i}$ as the number of home health care visits for a patient of type $i$. The cost of providing a unit of care intensity is $C$. I assume that $P$ is greater than $C$ to insure agency solvency. The agency's profits are equal to the number of patients of each type that it chooses to treat, $N_{i}$, multiplied by the perpatient profit for each type of patient: $\left(P \cdot I_{i}-C \cdot I_{i}\right)$. The number of patients treated, $N_{i}$, is constrained to be less than or equal to the number of patients who demand services from the agency, $D_{i}$, which is initially assumed to be exogenously determined. The Lagrangian is:

$$
L=N_{S} \cdot\left(P \cdot I_{S}-C \cdot I_{S}\right)+N_{L} \cdot\left(P \cdot I_{L}-C \cdot I_{L}\right)-\mu \cdot\left(N_{S}-D_{S}\right)-\gamma \cdot\left(N_{L}-D_{L}\right)
$$

The first-order conditions show that, because $P I_{i}$ is assumed to be greater than $C I_{i}$, the demand constraints must be binding. Agencies will treat as many patients of type $i$ as are available, because the marginal profit from treating an additional patient is always positive. The following graph shows the price and cost curves for long-term patients. As the first-order conditions suggest, $N_{L}$ is determined by $D_{L}$ in this graph. The graph for short-term patients is comparable. 


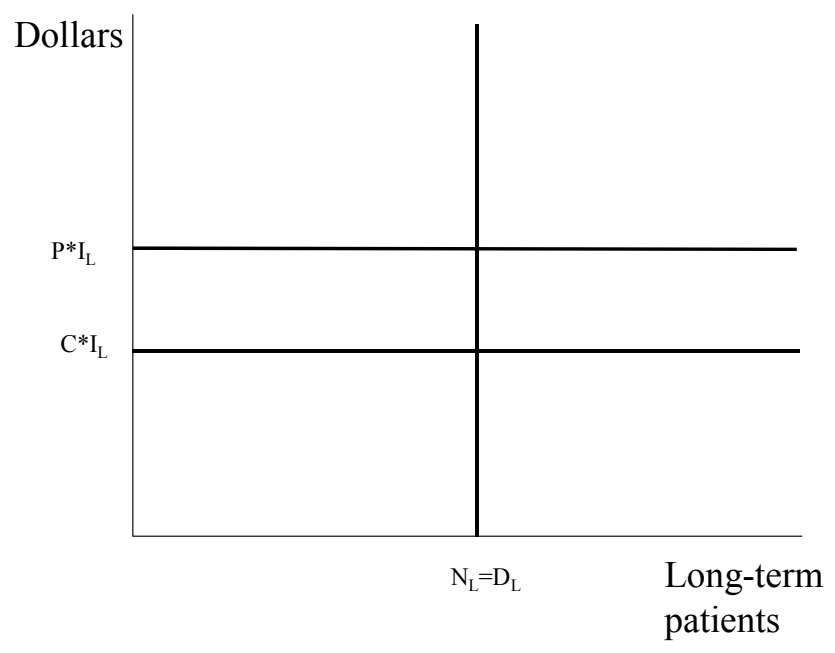

\section{Post-policy}

The policy change can be incorporated into this simple model by adding an average per-patient cap, $\bar{X}$, to the pre-policy reimbursement formula. Under the cap, reimbursements are restricted to be no greater than $\bar{X} \cdot\left(N_{S}+N_{L}\right)$. That is, an additional constraint is added to the profit maximization problem:

$$
P \cdot\left(N_{S} \cdot I_{S}+N_{L} \cdot I_{L}\right) \leq \bar{X} \cdot\left(N_{S}+N_{L}\right)
$$

For the purpose of the analysis, I assume that $P \cdot I_{S} \leq \bar{X} \leq C \cdot I_{L}$ and that the reimbursement constraint is binding.

It may seem counterintuitive that an agency would continue to treat long-term patients at all when $\bar{X} \leq C \cdot I_{L}$. However, an agency will continue to receive full pre-policy reimbursement for the marginal long-term patient $\left(P \cdot I_{L}\right)$ so long as the agency's average reimbursement 
remains below the per-patient cap $(\bar{X})$. Average reimbursement will remain below the cap as long as the agency treats enough short-term patients, whose costs all fall below the cap.

Agencies will maximize profit subject to the original demand constraints and subject to the new reimbursement constraint. The new Lagrangian is:

$$
\begin{aligned}
L= & N_{S} \cdot\left(P \cdot I_{S}-C \cdot I_{S}\right)+N_{L} \cdot\left(P \cdot I_{L}-C \cdot I_{L}\right) \\
& -\lambda \cdot\left(P \cdot\left(N_{S} \cdot I_{S}+N_{L} \cdot I_{L}\right)-\bar{X} \cdot\left(N_{S}+N_{L}\right)\right) \\
& -\mu \cdot\left(N_{S}-D_{S}\right)-\gamma \cdot\left(N_{L}-D_{L}\right)
\end{aligned}
$$

The new first-order conditions for profit maximization are therefore:

$$
\frac{d L}{d N_{S}}=\left(P \cdot I_{S}-C \cdot I_{S}\right)-\lambda \cdot\left(P \cdot I_{S}-\bar{X}\right)-\mu=0
$$

and:

$$
\frac{d L}{d N_{L}}=\left(P \cdot I_{L}-C \cdot I_{L}\right)-\lambda \cdot\left(P \cdot I_{L}-\bar{X}\right)-\gamma=0
$$

Because of the assumption that $P-C>0$, we know that the first term of (4) is positive.

Because of the assumption that $P \cdot I_{S} \leq \bar{X}$, we know that the second term of (4) is also positive. Therefore, in order to set the first-order condition equal to zero, it must be the case that $\mu$ is also positive. This fact implies that the constraint, $N_{S} \leq D_{S}$, is binding. In contrast, it is not necessarily true that the demand constraint for long-term patients, $N_{L} \leq D_{L}$, is binding, because the first term of (5) is positive and the second term of (5) is negative. Moreover, if the perpatient cap is a binding constraint on reimbursement, it follows that there is a single value of $N_{L}$, $N_{L}^{*}$, that maximizes agency profit. By the reimbursement constraint, it must be the case that: 
(6) $\quad N_{L}^{*}=\frac{D_{S} \cdot\left(\bar{X}-P \cdot I_{S}\right)}{\left(P \cdot I_{L}-\bar{X}\right)}$

This equation implies that the agency will treat more long-term patients as the demand among short-term patients increases, because each additional short-term patient eases the reimbursement cap. The agency will treat more long-term patients as the difference between the cap and $P \cdot I_{S}$ increases, because this difference also eases the cap. The agency will treat fewer long-term patients as the difference between the cap and $P \cdot I_{L}$ increases, because this difference increases the constraint imposed by the reimbursement cap. This equation highlights the link between the reimbursement that an agency receives for short-term patients and its ability to profitably treat any long-term patients. Reimbursement for short-term patients is always below the cap and, therefore, allows the agency to stay below the cap on average while collecting reimbursement above the cap for some long-term patients.

The following graph illustrates this point by showing the marginal reimbursement and marginal cost curves for long-term patients, for a given level of short-term patient demand. 


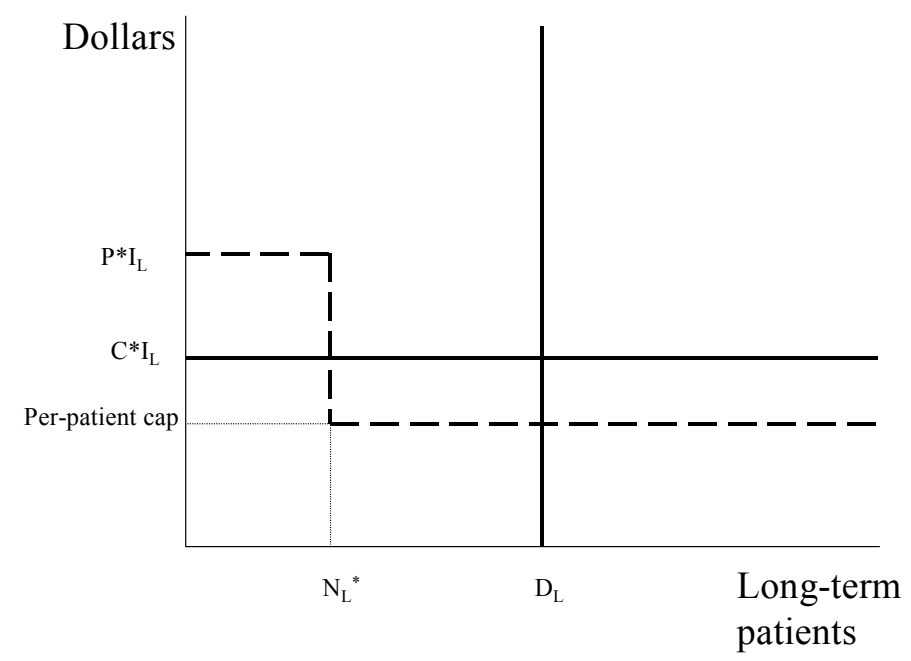

At points below $N_{L}^{*}$, the agency receives full reimbursement, $P \cdot I_{L}$, for each long-term patient, because there are enough short-term patients that the per-patient cap is not a binding constraint. Because the marginal profit from an additional long-term patient is positive, the agency will meet all demand in this range. At points above $N_{L}^{*}$, however, the agency receives only $\bar{X}$, which is below the cost, for each long-term patient. Per-patient marginal profits are negative in this range, so the agency will choose to provide care to no more than $N_{L}^{*}$ patients.

One element of this model that seems particularly unrealistic is the assumption that agencies cannot adjust $I_{i}$, the number of visits that they provide to a particular type of beneficiary. Solving a more detailed model, which allows for some adjustment of $I_{i}$ and assumes that demand is an increasing function of $I_{i}$, yields the same prediction as the simpler model, plus an additional prediction: agencies are more likely to decrease the intensity of care to long-term patients than to short-term patients. This new prediction reflects the fact that an increase in the intensity of care to short-term patients has the benefit of relaxing the demand constraint. 
Increasing intensity of care to long-term patients is less beneficial to the agency, however, since demand is less likely to be a constraint.

The insight provided by this model is that, under reasonable assumptions, agencies may attempt to increase the share of short-term patients in their caseload and may provide higher intensity of care to those patients in order to attract more of them. Agencies may also decrease the share of long-term patients and decrease the intensity of care provided to them. The differential impact of the average per-patient cap on the probability that long-term patients receive any care is an important prediction of the model and is tested in Section 6 of the paper. The prediction that the per-patient cap will differentially affect intensity of care for long-term patients, however, is not directly testable.

\section{Data and Empirical Strategy}

I use data from the MCBS to consider agency responses to the IPS and related changes in beneficiary utilization of care and health status. The MCBS surveys a rotating panel of Medicare beneficiaries, with an over-sampling of older beneficiaries. It combines administrative data from Medicare claims with survey data from several interviews with beneficiaries (or proxies, for beneficiaries who cannot participate in an interview) over the course of a year. The resulting data set provides information on utilization and costs of medical care, in addition to information on demographics and health status. Utilization and costs are categorized based on the type of care and the setting; categories include long-term facility, short-term institutional, inpatient, 
outpatient, medical provider, home health, hospice, and prescription drugs. ${ }^{5}$ The key dependent variables in my analyses are annual expenditures for each type of care.

The MCBS was conducted annually beginning in 1992. My data include 99,005 Medicare beneficiary observations from the 1992-1999 surveys, including 14,597 observations that report some home health utilization during the year. ${ }^{6}$ Of the home health users, 3,634 were in the post-policy period.

Summary statistics are provided in Table 1 . The first column shows statistics for the full sample. The second column provides summary statistics for observations that have relatively high predicted home care costs. Predicted costs were imputed based on each observation's characteristics and the coefficients from a regression of total home care costs on individual characteristics among those observations that had home health expenditures in the pre-policy period. The resulting predicted costs are a measure of the costs that each person was likely to have incurred if they had used home health care during the pre-policy period. The characteristics that were used to predict home care costs include age, gender, marital status, race, difficulties with walking, writing, lifting and stooping, as well as 18 diagnosis dummy variables. ${ }^{7}$ Table $2^{2}$ shows some of the coefficients on the characteristics that were used to impute predicted costs to the full sample. I define "high cost" beneficiaries as those individuals whose predicted costs are above $\$ 3,877$, the $75^{\text {th }}$ percentile prediction for all Medicare beneficiaries in the sample. The summary statistics in Table 1 show that the group with relatively high predicted costs has higher utilization levels of all forms of medical care than the predicted low-cost beneficiaries, reflecting

\footnotetext{
${ }^{5}$ Facility care and institutional care both refer to nursing home care; they are distinguished by the expected length of care. Medical provider events may refer to doctor visits, laboratory and surgical services, or purchases of medical equipment and supplies.

6 1,812 observations are excluded from the main analysis because of missing covariate values.

${ }^{7}$ Eighteen diagnosis dummy variables indicate whether an individual has ever received a diagnosis of Alzheimer's disease, angina pectoris, arthritis, broken hip, cancer, diabetes, emphysema, hardening of the arteries, hypertension, mental retardation, mental disorders, myocardial infarction, osteoporosis, other heart conditions, paralysis, Parkinson's disease, stroke, and amputation of an arm or leg.
} 
the relatively poor health of observations in the predicted high-cost group. In the empirical analysis, I test for differential impacts of the IPS on these two groups of beneficiaries.

I exploit state-level variation in the restrictiveness of IPS per-patient caps to identify the effect of the caps on beneficiary utilization of care and health outcomes. The predictions of the model were for individual agencies but they should also hold, on average, at the state level. Variation in restrictiveness arises from the fact that the per-patient cap was based on both the agency's historical costs and the region's average historical costs. Thus, agencies that had above-average costs within their region were penalized by the regional component of the cap and faced more restrictive caps; agencies that had below-average costs within their region benefited from the regional component of the cap and faced less restrictive caps.

For my empirical analysis, I create a measure of restrictiveness based on the 1994 state average visits per user, published in the Health Care Financing Review's annual statistical supplement. Restrictiveness technically depends on 1994 Medicare payments per user, but these payments - as well as the IPS caps - are adjusted across localities to reflect the differences in the costs of providing care. Thus, visits per user provide a measure of utilization that is more directly comparable across regions and yields a more accurate measure of actual restrictiveness than a measure using payment data. ${ }^{8}$ From each state's average visits per user in 1994, I subtract the average visits per user in that state's Census division, the relevant region for calculating perpatient caps. ${ }^{9}$ The resulting measure of restrictiveness ranges from -41 to +35 visits. In the analysis below, I use this measure, interacted with a dummy variable indicating the post-policy period, to identify the effects of the IPS. I define the post-policy period as the years 1998 and

\footnotetext{
${ }^{8}$ When a payment-based measure of restrictiveness is used, instead of the preferred visits-based measure, the results of the analysis are qualitatively unchanged.

${ }^{9}$ For 1999 data, I adjust the measure of restrictiveness to reflect increases in caps for those states that had average caps below the national median cap.
} 
1999; the last 3 months of 1997 are technically part of the post-policy period but, because the data is annual, these months are included with pre-policy data in my analysis. ${ }^{10}$

To graphically illustrate the basis for my identification strategy, I have classified states into "high", "medium" and "low" restrictiveness states, based on the continuous measure of restrictiveness that is used in regressions. Figures 4 and 5 use aggregate data from the Health Care Financing Review's annual statistical supplement to show that states with relatively restrictive caps had pre-policy trends that were similar to states with relatively unrestrictive caps, but experienced substantially larger post-policy declines in home care usage. ${ }^{11}$ States with relatively restrictive caps experienced a $32 \%$ decline in users per beneficiary and a $47 \%$ decline in visits per user between 1996 and 1999. In contrast, states with relatively unrestrictive caps experienced a $24 \%$ decline in users per beneficiary and a $37 \%$ decline in visits per user.

The basic estimating equation takes the following form:

$$
\begin{aligned}
Y_{\text {ist }}= & \alpha+\gamma_{1} \text { Re } \text { strict }_{s} * \text { Post }_{t}+X_{\text {ist }} \beta+\sum_{s} \phi_{s} \text { State }_{s}+\sum_{t} \eta_{t} \text { Year }_{t} \\
& +\sum_{s} \delta_{s} \text { State }_{s} * \text { trend }_{t}+\sum_{s} \phi_{h s} \text { State }_{s} * \text { HighCost }_{i}+\sum_{t} \eta_{h t} \text { Year }_{t} * \text { HighCost }_{i} \\
& +\sum_{s} \delta_{h s} \text { State }_{s} * \text { trend }_{t} * \text { HighCost }_{i}+\varepsilon_{\text {ist }}
\end{aligned}
$$

The coefficient of interest, $\gamma_{1}$, is on the interaction between the state-level measure of restrictiveness and the post-policy dummy variable; this coefficient is shown in the first row of each column in each of the tables that is discussed below. This coefficient measures the impact of living - during the post-policy period - in a state that provided an additional one visit per user above the regional average during the pre-policy period. I control separately for state and year fixed effects, state trends, as well as separate state and year fixed effects and state trends for

\footnotetext{
${ }^{10}$ The qualitative results of the analysis are not sensitive to exclusion of the 1997 data. The magnitudes of the effects on home health care are, as expected, larger when 1997 is excluded.

${ }^{11}$ Aggregate data for 1999 is from GAO (2000).
} 
beneficiaries with high predicted costs, and individual characteristics and diagnoses.

Coefficients for some of these control variables are shown in the lower rows of each table.

The main regressions of interest in my analysis use continuous dependent variables. I estimate these equations using OLS. For binary dependent variables, I report marginal effects from Probit estimation.

The critical identifying assumption of the empirical strategy is that there are no differential trends in states that faced relatively high restrictiveness due to the IPS. For example, if there were mean reversion in home care utilization, states with high pre-policy usage would experience decreases in utilization in the post-policy period, even in the absence of any policy change. Because states that faced relatively high restrictiveness also had relatively high prepolicy utilization levels, there is a possibility that my measure of restrictiveness simply captures the mean reversion of high utilization states. It is important to note, first of all, that there is no evidence of mean reversion in the pre-policy period (as shown in Figures 4 and 5), so it is not clear why we should expect mean reversion in the post-policy period.

Nevertheless, mean reversion is a concern and one of the ways that I address it is by using the fact that my measure of restrictiveness depends on a state's pre-policy utilization relative to other states in its region, not relative to the rest of the country. States that have similar pre-policy utilization may face the same degree of mean reversion, but would face different IPS restrictiveness depending on whether their utilization is higher or lower than other states in the division. ${ }^{12}$ Likewise, states that have very similar measures of restrictiveness had very different utilization levels in $1994 .^{13}$

\footnotetext{
${ }^{12}$ For instance, in 1994, home health users in Oklahoma received an average of 106 visits and users in Georgia received a comparable 102 visits (Health Care Financing Review 1996). However, the IPS was substantially more restrictive for Georgia, because the average home health user in Georgia in 1994 received 33 more visits than the
} 
In order to formally account for the possibility of mean reversion in my empirical analysis, I run my regressions both with and without a control for mean reversion. The mean reversion control variable is an interaction between the 1994 average visits per user in each state and a dummy variable for the post-policy period. This additional term accounts for the fact that states with high utilization in the pre-policy period may have decreased their utilization even in the absence of the IPS. As discussed below, the majority of my results are not sensitive to the inclusion of this additional term. This specification takes the following form:

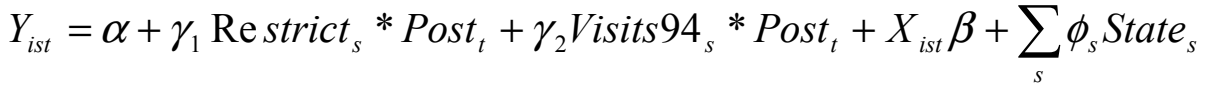

$$
\begin{aligned}
& +\sum_{t} \eta_{t} \text { Year }_{t}+\sum_{s} \delta_{s} \text { State }_{s} * \text { trend }_{t}+\sum_{s} \phi_{h s} \text { State }_{s} * \text { HighCost }_{i} \\
& +\sum_{t} \eta_{h t} \text { Year }_{t} * \text { HighCost }_{i}+\sum_{s} \delta_{h s} \text { State }_{s} * \text { trend }_{t} * \operatorname{HighCost}_{i}+\varepsilon_{\text {ist }}
\end{aligned}
$$

\section{Empirical Results}

\section{A. Effect on Home Health Care Utilization}

The results for home care utilization in Table 3 confirm the evidence from aggregate data: beneficiaries in states that had above-regional-average visits per user in 1994 had larger declines in home health care utilization in the post-policy period. To interpret the magnitude of the coefficients, I calculate the implied impact on a "typical" state, which received a perbeneficiary cap that precluded reimbursement for 6.32 visits that the typical pre-policy user received. The assumption that the per-beneficiary cap would permit reimbursement for 6.32

average user in the region; the average user in Oklahoma, in contrast, received only 4 more visits than the average user in the region.

${ }^{13}$ The restrictiveness measures for Kansas and Mississippi are 9 and 8, respectively, but users in Kansas in 1994 received an average of 56 visits, whereas users in Mississippi received an average of 114 visits (Health Care Financing Review 1996). 
fewer visits per user in a typical state is based on pre-policy utilization levels and HCFA's 1999 estimates of how tightly the caps constrained agency reimbursement. ${ }^{14}$

The first column of Table 3 shows results for a regression that controls only for state and year fixed effects and implies a decline of 3.4 visits per beneficiary in the "typical" state. The second column illustrates that the results are robust to inclusion of individual-level covariates, implying a decline of 3.3 visits per beneficiary in the typical state. The third column, which corresponds to the basic estimating equation specified in Equation 7, adds controls for state-level trends. The coefficient implies a decline of 4.9 visits per beneficiary in the typical state. Finally, the fourth column adds the interaction between 1994 state average visits per user and a postpolicy dummy variable. In this specification, the implied impact of the IPS is a decrease of 2.8 visits. In fact, average visits per beneficiary fell by 4.6 between 1996 and 1999, so each of these regressions suggests an impact of the IPS that is consistent with the aggregate data.

These regression results show the impact on average utilization of home health care. In Figures 6 and 7, I provide graphical evidence of the change in the distribution of home care visits in states with relatively unrestrictive caps (Figure 6) and in states with relatively restrictive caps (Figure 7). These figures suggest that the IPS led to a decline in the likelihood of receiving 50 or more visits, but did not substantially decrease the likelihood of receiving fewer than 50 visits. The fact that there was little change in the likelihood of receiving fewer than 50 visits could

\footnotetext{
${ }^{14}$ I begin with HCFA's estimate that agencies that faced binding constraints would exceed the cost limits by an average of $12 \%$ (Federal Register 1999). This $12 \%$ estimate is likely to understate the initial post-policy restrictiveness, since agencies had presumably adjusted some of their behavior by 1999. Applying this conservative $12 \%$ estimate to the average pre-policy (1996) utilization level of 73.6 visits per user, I determine that the typical agency that faced a binding cap provided 7.9 visits per user (in the pre-policy period) that would not be reimbursed in the post-policy period (Health Care Financing Review 1998). Then, accounting for HCFA's estimate that the per-patient cap was not a binding constraint for $21 \%$ of agencies, I determine that an average agency in an average state faced a cap that precluded reimbursement of 6.32 visits that the average pre-policy beneficiary received (Federal Register 1999). This provides a conservative estimate of the reimbursement constraint that the typical state faced after BBA 97. Since the coefficients in the tables measure the impact of a cap that precludes reimbursement for an additional 0.25 visits per user, I multiply the coefficient in the table by $25.28(6.32 * 4)$ in order to estimate the impact for a typical state.
} 
obscure changes in the composition of beneficiaries who received those visits. But the fact that the effects of the IPS are most visible in the upper part of the distribution suggests that the impact of the IPS may have been concentrated among those beneficiaries whose pre-policy utilization would have exceeded the per-patient caps.

The theoretical framework in Section 4 suggests that the negative impact of the IPS on utilization should be stronger for relatively unhealthy beneficiaries. Therefore, in results shown in Table 4, I interact the treatment variable with a dummy variable for having "high" predicted costs. ${ }^{15}$ The results for the basic estimating equation in column 3 reveal an impact on utilization among high-cost beneficiaries that is 29 times as large as the impact on low-cost beneficiaries. Moreover, the results in column 4, which control for mean reversion, suggest no decline in utilization among low-cost beneficiaries. Instead, in the typical state, beneficiaries with low predicted costs received an additional 1.5 home care visits, while beneficiaries with high predicted costs received 13.2 fewer home care visits.

There are two potential explanations for the larger declines among relatively unhealthy beneficiaries. The larger declines could reflect the fact that patients with high predicted costs use about six times more home care on average than those with low predicted costs and therefore had a greater opportunity to decrease utilization. The larger declines could also reflect a behavioral effect, arising from agencies' efforts to cut back on care to patients who were most likely to exceed per-patient caps. The results in Table 4 generally support the latter explanation. The results in column 3 suggest that, even as a share of mean home care use, the decline among highcost beneficiaries was greater than the decline among low-cost beneficiaries. Likewise, the

\footnotetext{
${ }^{15}$ These regressions also control for second-order interactions between the state measure of restrictiveness, the postpolicy dummy variable, and the high predicted costs dummy variable.
} 
results in column 4 indicate that the negative effects of the IPS on home health care usage were driven exclusively by significant negative effects among the predicted high cost beneficiaries.

In Table 5, I show basic results, estimated using Equation 8, for other measures of home health utilization. ${ }^{16}$ These results provide additional evidence that agencies responded to the IPS by differentially cutting back on care to relatively unhealthy beneficiaries. In particular, highcost beneficiaries faced a significant decline in the probability of receiving any Medicare home health care, whereas low-cost beneficiaries faced a significant increase. Likewise, high-cost beneficiaries experienced a significant decline in Medicare expenditures for home health care, whereas low-cost beneficiaries experienced a significant increase. For the typical state, the coefficients imply a \$365 decline in Medicare home care spending per high-cost beneficiary and an \$81 increase in Medicare home care spending per low-cost beneficiary.

It is unfortunately not possible to consider the impact of the IPS on the number of home health care visits, conditional on receiving any, because the IPS had an effect on the home care participation margin. However, it is possible to determine how much of the estimated effect on unconditional Medicare home care spending can be explained by the estimated change in Medicare home care participation implied by the coefficients in column 2 of Table 5 . If the predicted high-cost beneficiaries who stopped receiving any Medicare home health care after the IPS were average predicted high-cost users, the implied one percentage point decrease in the probability of receiving any home care explains only $11 \%$ of the $\$ 365$ unconditional decline in Medicare home health spending among high-cost users in the typical state. Thus, the remaining $89 \%$ of the unconditional decline must be explained either by a $\$ 1,062$ decrease in home care spending per user or by additional cream-skimming within the predicted high-cost beneficiaries (or by a combination of both).

\footnotetext{
${ }^{16}$ Results estimated using Equation 7 are similar and, therefore, are not shown.
} 


\section{B. Effects on Other Usage and Health Outcomes}

Tables 6 through 8 provide evidence on substitution between home health care and other types of care and are, therefore, relevant for assessing the overall effect of the IPS on efficiency in the production of medical care. The impact of IPS restrictiveness on long-term facility care is shown in Table 6. The coefficients indicate no significant effect of the IPS on the probability of using any long-term nursing home care or on expenditures among the high-cost or low-cost beneficiaries. ${ }^{17}$ The standard errors are sufficiently small that, for the typical state, I can reject increases in the likelihood of a high-cost beneficiary receiving any long-term facility care that are greater than 0.4 percentage points. Relative to the mean probability of any facility events for high-cost beneficiaries (27\%), this maximum 0.4 percentage point increase is relatively minor.

Because the results for measures of utilization of other types of care are similar to the results for long-term care facilities, I show only selected utilization measures in Tables 7 and 8. Although the results suggest no significant impact of the IPS on any of these expenditure measures, the standard errors are sufficiently large that it is impossible to reject a sizeable impact. Thus, the results for substitution towards other care are merely suggestive that there was no impact.

Because the IPS led to a large decline in home care usage among some of Medicare's most unhealthy beneficiaries, it provides a good opportunity to assess the benefits of home health care for beneficiary health outcomes. I use several measures of health, including body mass index (BMI), functional limitations and mortality. Table 9 shows the impact on BMI, the

\footnotetext{
${ }^{17}$ The finding of no substitution towards long-term facilities could, in theory, reflect the existence of excess demand for nursing home beds that has been previously reported. However, Grabowski (2001) summarizes the most recent evidence, which suggests a shift away from excess demand in the nursing home market in the 1980s and 1990s. Nursing home occupancy rates were roughly 89\% in 1996 (Harrington, Swan et al. 1998).
} 
probability of being underweight, and the probability of being overweight. Table 10 shows the effects on reported difficulties with three activities: stooping or kneeling, lifting 10 pounds, and walking 2-3 blocks. ${ }^{18}$ The dependent variable in each column is a dummy variable for reporting a lot of difficulty or an inability to perform the activity. In each case, there is no significant effect of the IPS. Finally, in results that are not reported in tables, I estimate effects on mortality, but do not find any impact. These measures of health outcomes are obviously quite coarse and, thus, should be interpreted as suggestive rather than conclusive. Nevertheless, they do not suggest any adverse health consequences associated with declines in home care.

There are several possible explanations for finding no evidence of a negative impact on health. For instance, it may be the case that the visits that were cut back after the IPS were less medically necessary than the visits that were not cut back. ${ }^{19}$ Another possible explanation is that the decline in publicly provided home health care visits led to an increase in informal care by family and friends. This explanation is not directly testable in the data. In addition, there may have been impacts on aspects of health or well-being that are not measured in this data, or impacts that affected only a small subset of patients rather than the overall Medicare population.

Another possible explanation for these findings is that individuals offset the reduction in Medicare-provided home health care visits by obtaining home health care through other sources of payment. Thus, in Table 11, I show the impact of the IPS on total home health care spending, and decompose the impact among the three largest sources of payment for home care: Medicare,

\footnotetext{
${ }^{18}$ These regressions necessarily exclude functional limitations from the set of explanatory variables and from the home care cost prediction equations. This change raises the question of whether functional limitations should be used as control variables in any regressions, since they are potential outcomes. Results that are not shown in the tables reveal that my findings are not sensitive to the exclusion of functional limitation control variables.

${ }^{19}$ McCall et al. (2001) report that the composition of Medicare home health visits shifted away from home health aide visits and towards skilled care after BBA 97. If the home health aide visits provided the least marginal medical value, it may not be surprising that there are no observable adverse impacts on health status.
} 
Medicaid and beneficiary out-of-pocket expenditures. ${ }^{20}$ I do not find a significant increase in Medicaid home health care spending, but I do find a significant increase in out-of-pocket home health spending among high-cost beneficiaries. In particular, twenty-two percent of the estimated decline in Medicare spending among high-cost beneficiaries was offset by increases in out-of-pocket expenditures. This finding is consistent with aggregate data, which indicate that out-of-pocket expenditures for home- and community-based long-term care for the elderly nearly doubled between 1995 and 2000, rising from $\$ 6$ billion to $\$ 11$ billion (U.S. Congress 1998 , 2000). The evidence, therefore, suggests that some of the cost savings from the IPS were not, in the broadest terms, cost savings; rather, the costs were shifted to other payers.

Given that some of the decline in Medicare home health care was offset by increases in out-of-pocket expenditures, an important question is whether lower income beneficiaries - who may not be able to afford to pay for their own home health care-experienced larger declines in home health care. Table 12 shows key regression coefficients separately for beneficiaries with incomes below and above the poverty line. Columns 1 and 4 show the means of the dependent variables for the low- and high-income sub-samples. Columns 2 and 5 show the coefficient on the interaction between a post-policy dummy variable and the state-level restrictiveness measure. Columns 3 and 6 show the coefficient (from the same regression) on the interaction between the predicted high-cost dummy variable, the post-policy dummy variable, and the restrictiveness measure.

The most striking difference between high- and low-income beneficiaries is that lowincome beneficiaries did not offset Medicare spending reductions with out-of-pocket expenditures. Rather, the increases in out-of-pocket expenditures were concentrated among the

\footnotetext{
${ }^{20}$ There is likely to be more under-reporting in the non-Medicare payments for home health care, because these data are based only on survey responses, rather than administrative data.
} 
high-income beneficiaries, who offset $63 \%$ of Medicare's spending decreases. As a result, highincome beneficiaries experienced substantially smaller declines in home care use than lowincome beneficiaries. The results imply that high-income beneficiaries with high predicted costs in a typical state received 8.8 fewer visits per beneficiary after the IPS; low-income beneficiaries with high predicted costs in the same state received 19.4 fewer visits.

The table also shows coefficients for several key measures of health care utilization and health outcomes, separately by income level. These results provide little evidence of substitution towards other types of care or of adverse health outcomes, even among the lower-income subsample that experienced larger net declines in home care utilization.

One concern about the results is the issue of external validity. If the IPS led agencies to cut back on precisely those home care visits that had the lowest marginal medical value, it is possible that further cuts would induce observable declines in health status in the overall Medicare population. Another caveat to the present results is that they represent short-run outcomes. Some agencies may have required a year to fully ascertain the implications of the reimbursement changes or to fully incorporate changes to their procedures. ${ }^{21}$ Likewise, it is possible that some effects on health outcomes would not become immediately apparent. Thus, the results that are reported here could be an overestimate or underestimate of the long-run impact of the IPS.

\section{Identification and Specification Checks}

I find that the results are robust to a variety of specification checks: using different cutoffs for "high" predicted costs, allowing separate effects of the IPS for all four quartiles of the

\footnotetext{
${ }^{21}$ Indeed, when the IPS effects on home care utilization are separated into effects for 1998 and 1999, the magnitude of the 1998 effect is larger. This finding may suggest that agencies initially over-reacted to the IPS and moderated their response in the longer-run.
} 
distribution of predicted $\operatorname{costs}^{22}$, using cross-sectional weights, using state average visits per user in 1996 (rather than 1994) for the mean reversion control variable, excluding functional limitations as explanatory variables, controlling for the use of a proxy to answer survey questions, restricting the sample to aged beneficiaries, and restricting the sample to beneficiaries with fee-for-service Medicare coverage.

Also, as a further test for problems of mean reversion, I exclude the actual post-policy period from the analysis, designate the years 1995, 1996 and 1997 as "post-policy" years, and replicate the analysis in Tables 3, 4 and 5. The IPS caps were based on utilization in 1994 so, if mean reversion were truly driving the results in Tables 3, 4 and 5, we would find similar coefficients in this falsification exercise in spite of the fact that the IPS did not yet exist. However, whereas the coefficient for the actual analysis in column 4 of Table 3 is -.109 , a comparable coefficient in the falsification exercise is +.135 , significant at the $10 \%$ level. For every other measure of home health care utilization, the coefficient of interest, $\gamma_{1}$, in the falsification exercise consistently takes the opposite sign from the coefficient in the true analysis. Thus, these results confirm that mean reversion is not driving my findings.

One concern with the identification strategy is that there could be some correlation between my measure of the restrictiveness of the home health reimbursement cap and the restrictiveness of Medicare's PPS for SNFs, which was implemented in 1998. In fact, there does seem to be a correlation between the restrictiveness of the IPS and the restrictiveness of the SNF PPS. In addition to identifying a negative impact on home health utilization, the measure of IPS restrictiveness identifies a negative "impact" of the home health reimbursement caps on SNF

\footnotetext{
${ }^{22}$ The effects of the IPS on the first three quartiles of predicted costs are generally statistically indistinguishable from one another.
} 
utilization. In order to address this issue, I test the sensitivity of my results to using two alternative sub-samples of the data that avoid contamination from the SNF policy change.

In one specification check, I exclude any beneficiaries who had an inpatient hospital stay during the year. Medicare covers SNF stays only following inpatient hospital stays, so the change in Medicare reimbursement should have had no impact on beneficiaries who had no inpatient stays. When I restrict my data set to this sub-sample, I no longer identify a decline in SNF utilization. In another specification check, I exclude 1998 and 1999 data from the analysis. This strategy has the substantial drawback of cutting out most of the "post-policy" period, leaving only 1997 as a "treated" period. It does, however, accomplish the goal of excluding any effects of the SNF policy change, since the SNF change occurred in mid-1998. Using this subsample, there is again no evidence of a decline in SNF utilization. Both alternative analyses yield results that are otherwise comparable to the main analysis.

Given the substantial state-to-state variation in pre-policy utilization that underlies the measure of restrictiveness, a natural question is what generated these regional differences. For example, if this variation was driven entirely by differences in the health status of state residents, the restrictiveness measure could be simply measuring the differential trends in utilization by beneficiaries with different health statuses. However, there is little evidence that the large prepolicy differences are primarily attributable to differences in patient characteristics. ${ }^{23}$

In one analysis of the geographic variation, GAO (1996) showed that some states consistently provided more care than other states, even among patients with the same diagnosis, in data from the early 1990s. Schore (1994) used detailed data about patient characteristics and diagnoses as well as regional and agency characteristics and was able to explain only about one-

\footnotetext{
${ }^{23}$ Wide geographic variation in overall Medicare expenditures has also been documented, with little evidence that differences in underlying beneficiary health can explain the variation. See, for example, Skinner and Fisher (1997).
} 
third of the regional variation in the number of visits per episode of care in her data from the early 1990s. She proposes differences in physician and agency practice patterns, differences in the availability of nursing home or home- and community-based care, and unobservable patient characteristics as potential explanations for the remaining variation. Other research suggests that the supply of substitutes for Medicare home health care explains some portion of the historical geographic variation in home health care usage. ${ }^{24}$ Taken together, the existing research on state variation in Medicare home health care spending suggests that the variation-while not fully explained — was largely attributable to a variety of historical supply factors and differences in practice styles.

\section{Conclusion}

Long-term care is a policy issue that will become increasingly important in the coming decades. Murtaugh et al. (1997) estimate that a person who reached the age of 65 in 1995 had a $39 \%$ chance of being admitted to a nursing home during his or her remaining lifetime. Thus, as the population ages, it will become increasingly important for policy-makers to consider options for long-term care policy and, in particular, whether home health care can provide a costeffective substitute for nursing home care. This paper uses a substantial change in Medicare's home care reimbursement policy to provide evidence on several important issues in long-term care policy and draws several conclusions.

I find that the provision of home health care is quite sensitive to the structure of reimbursement. In particular, when Medicare augmented its traditional fee-for-service

\footnotetext{
${ }^{24}$ For example, Cohen and Tumlinson (1997), Kenney and Dubay (1992), and Swan and Benjamin (1990) all document an inverse relationship between the supply of nursing home care and the utilization of home health care. Likewise, Cohen and Tumlinson (1997) and Kenney and Rajan (2000) find a negative relationship between Medicaid home health spending and Medicare home health utilization.
} 
reimbursement with a more prospective, average per-patient cap, home health agencies responded by reducing care to relatively unhealthy beneficiaries. Nevertheless, in spite of dramatic reductions in home health care utilization, I find no evidence that beneficiaries were more likely to move to long-term facilities. This finding is consistent with earlier research that has suggested limited scope for substitution between home health care and nursing home care. I also find no evidence of increased expenditures for other types of medical care or of adverse consequences for beneficiary health.

The empirical results highlight several potential sources of efficiency change. First, the reimbursement change led to a decline in consumption of home health care that was valued below its marginal cost, but had been consumed during the pre-policy period due to the absence of cost-sharing. While the IPS did not explicitly impose any cost-sharing, it led to a decrease in the availability of home health care for those beneficiaries who were not willing to make out-ofpocket payments. In fact, out-of-pocket expenditures offset only $22 \%$ of the decline in Medicare expenditures, suggesting that $78 \%$ of the spending that was cut back after BBA 97 was for care that was valued by beneficiaries at less than its market price. This decline in the over-provision of home health care represents a welfare gain.

The empirical results suggest that there was considerable variation in responsiveness across different types of beneficiaries. For instance, low-income beneficiaries exhibited more elastic demand for home health care than relatively high-income beneficiaries. This finding may reflect the fact that low-income beneficiaries have a relatively high marginal utility from nonhealth consumption, such as food and clothing, due to their low income. If the social welfare function favors health care utilization patterns that are determined solely by health status and not 
by income, however, it is possible that low-income beneficiaries responded to the IPS by underconsuming home health care, which would represent welfare loss.

The IPS also generated welfare loss by raising the level of financial risk faced by Medicare beneficiaries. That is, the IPS increased the out-of-pocket liability faced by relatively unhealthy beneficiaries, who already face larger out-of-pocket medical expenditures than healthy beneficiaries. The welfare loss is the risk premium that a Medicare beneficiary would be willing to pay to fully insure against the risk of being a beneficiary with high predicted home care costs, after the imposition of the IPS. The exact level of the risk premium depends on assumptions about the form of the utility function, the degree of risk aversion in the Medicare population, and the minimum level of non-medical consumption guaranteed by society to beneficiaries whose medical expenses exceed their incomes.

Taken together, the welfare implications are ambiguous. Depending on assumptions about the social welfare and individual utility functions, it is possible that the policy change either increased or decreased social welfare. 


\section{References}

Bishop, Christine (1999). "Where are the Missing Elders? The Decline in Nursing Home Use, 1985 and 1995," Health Affairs 18(4).

Chalkley, Martin and James M. Malcomson (2000). "Government Purchasing of Health Services" in Handbook of Health Economics, Volume I, edited by A. J. Culyer and J. P. Newhouse (New York: Elsevier Science).

Cheh, Valerie (2001). "The Final Evaluation Report on the National Home Health Prospective Payment Demonstration: Agencies Reduce Visits While Preserving Quality," Princeton, NJ: Mathematica Policy Research, Inc.

Cohen, Marc A. and Anne Tumlinson (1997). "Understanding the State Variation in Medicare Home Health Care: The Impact of Medicaid Program Characteristics, State Policy, and Provider Attributes," Medical Care 35(6): 618-633.

Congressional Budget Office (1997). "Budgetary Implications of the Balanced Budget Act of 1997," Washington D.C.:CBO.

Federal Register, March 31, 1998, U.S. Office of the Federal Register, National Archives and Records Service, General Services Administration, Washington, D.C.: U.S. Government Printing Office.

Federal Register, August 5, 1999, U.S. Office of the Federal Register, National Archives and Records Service, General Services Administration, Washington, D.C.: U.S. Government Printing Office.

Goldberg, Henry B. and Robert J. Schmitz (1994), "Contemplating Home Health PPS: Current Patterns of Medicare Service Use," Health Care Financing Review 16(1): $109-130$

Grabowski, David C. (2001). "Medicaid Reimbursement and the Quality of Nursing Home Care," Journal of Health Economics 20: 549-569.

Health Care Financing Administration (various years). Health Care Financing Review, Medicare and Medicaid Statistical Supplement. Washington, DC.: GPO.

Hadley, Jack, David Rabin, Andrew Epstein, Susan Stein, and Carolyn Rimes (2000). "Posthospitalization Home Health Care Use and Changes in Functional Status in a Medicare Population," Medicare Care 38(5): 494-507.

Harrington, Charlene, James Swan et al. (1998). “1996 State Data Book on Long Term Care Program and Market Characteristics."

Hughes, Susan, Larry Manheim, Perry Edelman and Kendon Conrad (1987). "Impact of 
Long-Term Home care on hospital and nursing home use and cost," Health Services Research 22(1): 19-47.

Kemper, Peter (1988), "The Evaluation of the National Long Term Care Demonstration: Overview of the findings," Health Services Research 23(1):162-174.

Kenney, Genevieve M. and Lisa C. Dubay (1992). "Explaining Area Variation in the Use of Medicare Home Health Services," Medical Care 30(1): 43-57.

Kenney, Genevieve and Shruti Rajan (2000). "Understanding Dual Enrollees' Use of Medicare Home Health Services: The Effects of Differences in Medicaid Home Care Programs," Medical Care 38(1): 90-98.

Liu, Korbin, Barbara Gage, Jennie Harvell, David Stevenson and Niall Brennan (1999). "Medicare's Post-Acute Care Benefit: Background, Trends, and Issues to Be Faced," The Urban Institute.

McCall, Nelda, Harriet L. Komisar, Andrew Petersons, and Stanley Moore (2001). "Medicare Home Health Before and After the BBA," Health Affairs 20(3): 189-198.

Medicare Payment Advisory Commission (1999). Report to the Congress: Selected Medicare Issues (Washington, DC: MedPAC).

Murtaugh, Christopher, Peter Kemper, Brenda Spillman, and Barabara Lepidus Carlson (1997). "The Amount, Distribution, and Timing of Lifetime Nursing Home Use," Medical Care 35(3): 204-218.

Newhouse, Joseph P (1996). "Reimbursing Health Plans and Health Providers: Efficiency in Production Versus Selection," Journal of Economic Literature 34(3): 12361263.

Newhouse, Joseph P (2002). "Medicare" in American Economic Policy in the 1990s, edited by Jeffrey A. Frankel and Peter R. Orszag (Cambridge, MA: MIT Press): 899-955.

Norton, Edward C (2000). "Long-Term Care" in Handbook of Health Economics, Volume I, edited by A. J. Culyer and J. P. Newhouse (New York: Elsevier Science).

Office of the Inspector General, U.S. Department of Health and Human Services (2001). "Review of Medicare Home Health Services in Florida," Report A-04-99-01195.

Phillips, Barbara, Randall Brown, Christine Bishop, Amy Klein, Grant Ritter, Jennifer Schore, Kathleen Skwara, and Craig Thornton (1999). "Do Present Per Visit Payment Rates Affect Home Care Health Behavior?," Health Care Financing Review 16, No. 1: 91-107. 
Schore, Jennifer (1994). "Patient, Agency, and Area Characteristics Associated with Regional Variation in the Use of Medicare Home Health Services, Princeton, NJ: Mathematica Policy Research, Inc.

Skinner, Jonathan and Elliot Fisher (1997). "Regional Disparities in Medicare Expenditures: An Opportunity for Reform,” National Tax Journal L(3): 413-426.

Swan, James H. and A. E. Benjamin (1990). "Medicare Home Health Utilization as a Function of Nursing Home Market Factors," Health Services Research 25(3): 479-500.

United State Congress, Committee on Ways and Means (1998). Green Book 1998: Background Material on Programs Under the Jurisdiction of the Committee on Ways and Means, Washington D.C.: GPO.

United State Congress, Committee on Ways and Means (2000). Green Book 2000: Background Material on Programs Under the Jurisdiction of the Committee on Ways and Means, Washington D.C.: GPO.

United States Department of Health and Human Services (2002). Health, United States, 2002 (Washington D.C.: GPO).

United States General Accounting Office (1998). "Medicare: Interim Payment System for Home Health Agencies," Testimony of William J. Scanlon before the Subcommittee on Health, Committee on Ways and Means, House of Representatives, August 6.

United States General Accounting Office (1999). "Medicare Home Health Agencies: Closures Continue, with Little Evidence Beneficiary Access is Impaired," GAO Report HEHS-99-120

United States General Accounting Office (1998). "Medicare Home Health Benefit: Impact of Interim Payment System and Agency Closures on Access to Services," GAO Report HEHS-98-238.

United States General Accounting Office (2000). "Medicare Home Health Care: Prospective Payment System Could Reverse Recent Declines in Spending," GAO Report HEHS-00-176.

United States General Accounting Office (1997). "Medicare Home Health: Success of Balanced Budget Act Cost Controls Depends on Effective and Timely Implementations," Testimony of William J. Scanlon before the Subcommittee on Oversight and Investigations, Committee on Commerce, House of Representatives, October 27.

United States General Accounting Office (1996). "Medicare: Home Health Utilization Expands While Program Controls Deteriorate," GAO Report HEHS-96-16. 
Table 1: Summary statistics

Means and standard deviations

\begin{tabular}{|c|c|c|c|}
\hline Variable & Full sample & $\begin{array}{c}\text { Predicted High- } \\
\text { Cost Beneficiaries }\end{array}$ & $\begin{array}{c}\text { Predicted Low- } \\
\text { Cost Beneficiaries }\end{array}$ \\
\hline Predicted home care costs & $\begin{array}{l}2927 \\
(2351)\end{array}$ & $\begin{array}{c}6224 \\
(2070)\end{array}$ & $\begin{array}{c}1828 \\
(1056)\end{array}$ \\
\hline Home health events & $\begin{array}{c}12.59 \\
(63.95)\end{array}$ & $\begin{array}{c}34.04 \\
(104.52)\end{array}$ & $\begin{array}{c}5.45 \\
(40.09)\end{array}$ \\
\hline Any home health events & $\begin{array}{l}.150 \\
(.357)\end{array}$ & $\begin{array}{l}.314 \\
(.464)\end{array}$ & $\begin{array}{l}.096 \\
(.294)\end{array}$ \\
\hline Home health events, conditional on any & $\begin{array}{c}83.85 \\
(145.79)\end{array}$ & $\begin{array}{c}108.49 \\
(163.54)\end{array}$ & $\begin{array}{c}56.93 \\
(117.77)\end{array}$ \\
\hline Expenditures & $\begin{array}{c}446 \\
(3256)\end{array}$ & $\begin{array}{l}1357 \\
(6074)\end{array}$ & $\begin{array}{c}143 \\
(1215)\end{array}$ \\
\hline Medicare home health expenditures & $\begin{array}{c}399 \\
(2368)\end{array}$ & $\begin{array}{l}1148 \\
(4134)\end{array}$ & $\begin{array}{c}131 \\
(1096)\end{array}$ \\
\hline Medicaid home health expenditures & $\begin{array}{c}8 \\
(1377)\end{array}$ & $\begin{array}{c}24 \\
(2632)\end{array}$ & $\begin{array}{c}2 \\
(216)\end{array}$ \\
\hline Out-of-pocket home health expenditures & $\begin{array}{c}30 \\
(1653)\end{array}$ & $\begin{array}{c}96 \\
(3126)\end{array}$ & $\begin{array}{c}6 \\
(378)\end{array}$ \\
\hline Facility events & $\begin{array}{l}.105 \\
(.335)\end{array}$ & $\begin{array}{c}.291 \\
(.501)\end{array}$ & $\begin{array}{c}.043 \\
(.226)\end{array}$ \\
\hline Any events & $\begin{array}{l}.097 \\
(.296)\end{array}$ & $\begin{array}{l}.270 \\
(.444)\end{array}$ & $\begin{array}{l}.039 \\
(.194)\end{array}$ \\
\hline Events, conditional on any & $\begin{array}{l}1.08 \\
(.32)\end{array}$ & $\begin{array}{l}1.08 \\
(.29)\end{array}$ & $\begin{array}{l}1.10 \\
(.36)\end{array}$ \\
\hline Expenditures & $\begin{array}{c}2875 \\
(12813)\end{array}$ & $\begin{array}{c}7896 \\
(18496)\end{array}$ & $\begin{array}{c}1202 \\
(9679)\end{array}$ \\
\hline Inpatient events & $\begin{array}{l}.373 \\
(.956)\end{array}$ & $\begin{array}{c}.649 \\
(1.239)\end{array}$ & $\begin{array}{l}.281 \\
(.821)\end{array}$ \\
\hline Any events & $\begin{array}{l}.217 \\
(.412)\end{array}$ & $\begin{array}{l}.348 \\
(.476)\end{array}$ & $\begin{array}{l}.174 \\
(.379)\end{array}$ \\
\hline events, conditional on any & $\begin{array}{c}1.72 \\
(1.38)\end{array}$ & $\begin{array}{l}1.87 \\
(1.46)\end{array}$ & $\begin{array}{c}1.62 \\
(1.31)\end{array}$ \\
\hline Expenditures & $\begin{array}{c}2836 \\
(9518)\end{array}$ & $\begin{array}{c}4902 \\
(12999)\end{array}$ & $\begin{array}{c}2147 \\
(7911)\end{array}$ \\
\hline Outpatient events & $\begin{array}{c}3.74 \\
(9.53)\end{array}$ & $\begin{array}{c}5.20 \\
(11.91)\end{array}$ & $\begin{array}{c}3.25 \\
(8.54)\end{array}$ \\
\hline Any events & $\begin{array}{l}.661 \\
(.473)\end{array}$ & $\begin{array}{l}.737 \\
(.440)\end{array}$ & $\begin{array}{l}.635 \\
(.481)\end{array}$ \\
\hline events, conditional on any & $\begin{array}{c}5.65 \\
(11.26)\end{array}$ & $\begin{array}{c}7.06 \\
(13.39)\end{array}$ & $\begin{array}{c}5.11 \\
(10.26)\end{array}$ \\
\hline Expenditures & $\begin{array}{c}812 \\
(3160)\end{array}$ & $\begin{array}{l}1128 \\
(3685)\end{array}$ & $\begin{array}{l}707 \\
(2957)\end{array}$ \\
\hline Observations & 97,193 & 24,293 & 72,900 \\
\hline
\end{tabular}


Table 1: Summary Statistics, continued

\begin{tabular}{|c|c|c|c|}
\hline Variable & Full sample & $\begin{array}{l}\text { Predicted High- } \\
\text { Cost Beneficiaries }\end{array}$ & $\begin{array}{l}\text { Predicted Low- } \\
\text { Cost Beneficiaries }\end{array}$ \\
\hline Medical provider events & $\begin{array}{l}22.05 \\
(28.00)\end{array}$ & $\begin{array}{c}31.58 \\
(36.29)\end{array}$ & $\begin{array}{l}18.88 \\
(23.78)\end{array}$ \\
\hline Any events & $\begin{array}{l}.944 \\
(.231)\end{array}$ & $\begin{array}{l}.959 \\
(.198)\end{array}$ & $\begin{array}{l}.938 \\
(.241)\end{array}$ \\
\hline Events, conditional on any & $\begin{array}{c}23.37 \\
(28.28)\end{array}$ & $\begin{array}{c}32.93 \\
(36.46)\end{array}$ & $\begin{array}{l}20.12 \\
(24.04)\end{array}$ \\
\hline Expenditures & $\begin{array}{c}2094 \\
(4173)\end{array}$ & $\begin{array}{c}3079 \\
(5528)\end{array}$ & $\begin{array}{c}1765 \\
(3549)\end{array}$ \\
\hline Age & $\begin{array}{c}72.02 \\
(14.34)\end{array}$ & $\begin{array}{c}76.01 \\
(15.37)\end{array}$ & $\begin{array}{c}70.69 \\
(13.73)\end{array}$ \\
\hline Male & .436 & .295 & .483 \\
\hline Married & .472 & .330 & .520 \\
\hline Body Mass Index & $\begin{array}{l}25.38 \\
(6.23)\end{array}$ & $\begin{array}{l}24.30 \\
(8.43)\end{array}$ & $\begin{array}{l}25.73 \\
(5.27)\end{array}$ \\
\hline Underweight & .068 & .151 & .040 \\
\hline Overweight & .510 & .448 & .530 \\
\hline Difficulty stooping & .167 & .571 & .032 \\
\hline Difficulty lifting & .159 & .552 & .028 \\
\hline Difficulty writing & .030 & .119 & .0001 \\
\hline Difficulty walking & .225 & .715 & .062 \\
\hline Died & .054 & .126 & .030 \\
\hline
\end{tabular}




\section{Table 2: Coefficients Used to Predict Home Care Costs}

\begin{tabular}{|c|c|}
\hline Independent Variable & $\begin{array}{c}\text { Coefficient } \\
\text { (Standard error) }\end{array}$ \\
\hline Male & $\begin{array}{c}-31 \\
(416)\end{array}$ \\
\hline Married & $\begin{array}{l}872 * * \\
(402)\end{array}$ \\
\hline Male*Married & $\begin{array}{c}-1704 * * \\
(612)\end{array}$ \\
\hline Some difficulty stooping & $\begin{array}{c}206 \\
(416)\end{array}$ \\
\hline Lots of difficulty stooping & $\begin{array}{c}1411^{* *} \\
(488)\end{array}$ \\
\hline Some difficulty lifting $10 \mathrm{lbs}$ & $\begin{array}{c}-25 \\
(406)\end{array}$ \\
\hline Lots of difficulty lifting $10 \mathrm{lbs}$ & $\begin{array}{c}1003 * * \\
(435)\end{array}$ \\
\hline Some difficulty walking 2-3 blocks & $\begin{array}{c}446 \\
(439)\end{array}$ \\
\hline Lots of difficulty walking 2-3 blocks & $\begin{array}{c}1420^{* *} \\
(458)\end{array}$ \\
\hline Some difficulty writing & $\begin{array}{l}586^{*} \\
(322)\end{array}$ \\
\hline Lots of difficulty writing & $\begin{array}{c}4019^{* *} \\
(538)\end{array}$ \\
\hline Diabetes & $\begin{array}{l}791 * * \\
(314)\end{array}$ \\
\hline Stroke & $\begin{array}{l}609^{*} \\
(345)\end{array}$ \\
\hline Alzheimer's & $\begin{array}{c}290 \\
(485)\end{array}$ \\
\hline Broken hip & $\begin{array}{c}396 \\
(412)\end{array}$ \\
\hline
\end{tabular}

This table shows coefficients from a regression on the sub-sample of beneficiaries who used home health care during the pre-policy period. The dependent variable is home health care costs. Other predictors of home health care costs include: age group, race, and other health conditions (amputation of an arm or leg, angina pectoris, arthritis, cancer, emphysema, hardening of the arteries, hypertension, mental retardation, mental disorders, myocardial infarction, osteoporosis, other heart conditions, paralysis, and Parkinson's disease). 
Table 3: Home Health Utilization

\begin{tabular}{|c|c|c|c|c|}
\hline Independent variable & $\begin{array}{c}(1) \\
\text { Visits }\end{array}$ & $\begin{array}{c}(2) \\
\text { Visits }\end{array}$ & $\begin{array}{c}(3) \\
\text { Visits }\end{array}$ & $\begin{array}{c}(4) \\
\text { Visits }\end{array}$ \\
\hline Post-BBA 97*Restrict & $\begin{array}{c}-.133 * * \\
(.036)\end{array}$ & $\begin{array}{c}-.130 * * \\
(.037)\end{array}$ & $\begin{array}{c}-.192 * * \\
(.048)\end{array}$ & $\begin{array}{l}-.109 * \\
(.057)\end{array}$ \\
\hline \multicolumn{5}{|l|}{ Personal Characteristics } \\
\hline Male & & $\begin{array}{c}.284 \\
(.700)\end{array}$ & $\begin{array}{l}.285 \\
(.698)\end{array}$ & $\begin{array}{c}.283 \\
(.697)\end{array}$ \\
\hline Married & & $\begin{array}{c}-2.638 * * \\
(.687)\end{array}$ & $\begin{array}{c}-2.590 * * \\
(.684)\end{array}$ & $\begin{array}{c}-2.596 * * \\
(.684)\end{array}$ \\
\hline Male*Married & & $\begin{array}{l}-.376 \\
(.862)\end{array}$ & $\begin{array}{l}-.400 \\
(.858)\end{array}$ & $\begin{array}{c}-.389 \\
(.858)\end{array}$ \\
\hline Predicted Cost & & $\begin{array}{l}.0007 * * \\
(.0003)\end{array}$ & $\begin{array}{l}.0008 * * \\
(.0003)\end{array}$ & $\begin{array}{c}.0008 * * \\
(.0003)\end{array}$ \\
\hline Diabetes & & $\begin{array}{c}3.161 * * \\
(.645)\end{array}$ & $\begin{array}{c}3.120 * * \\
(.645)\end{array}$ & $\begin{array}{c}3.123 * * \\
(.645)\end{array}$ \\
\hline Stroke & & $\begin{array}{c}2.488 * * \\
(.969)\end{array}$ & $\begin{array}{c}2.444 * * \\
(.971)\end{array}$ & $\begin{array}{c}2.459 * * \\
(.972)\end{array}$ \\
\hline Alzheimer's & & $\begin{array}{c}-2.012 \\
(2.065)\end{array}$ & $\begin{array}{l}-2.095 \\
(2.079)\end{array}$ & $\begin{array}{l}-2.095 \\
(2.079)\end{array}$ \\
\hline Year fixed effects & Yes & Yes & Yes & Yes \\
\hline State fixed effects & Yes & Yes & Yes & Yes \\
\hline State trends & No & No & Yes & Yes \\
\hline Visits94*Post & No & No & No & Yes \\
\hline Observations & 97,193 & 97,193 & 97,193 & 97,193 \\
\hline
\end{tabular}

Other control variables include year, state, state trends, age group, race, education, income, and other health conditions (amputation of arm or leg, angina pectoris, arthritis, broken hip, cancer, emphysema, hardening of the arteries, hypertension, mental retardation, mental disorders, myocardial infarction, osteoporosis, other heart conditions, paralysis, and Parkinson's disease) and level of difficulty with walking, writing, lifting and kneeling. Equations are estimated using OLS. Standard errors are clustered on state and year. 
Table 4: Home Health Utilization

\begin{tabular}{|c|c|c|c|c|}
\hline Independent variable & $\begin{array}{c}(1) \\
\text { Visits }\end{array}$ & $\begin{array}{c}(2) \\
\text { Visits }\end{array}$ & $\begin{array}{c}(3) \\
\text { Visits }\end{array}$ & $\begin{array}{c}(4) \\
\text { Visits }\end{array}$ \\
\hline Post-BBA $97 *$ Restrict & $\begin{array}{c}-.049 * * \\
(.024)\end{array}$ & $\begin{array}{c}-.058 * * \\
(.025)\end{array}$ & $\begin{array}{l}-.020 \\
(.032)\end{array}$ & $\begin{array}{l}.058 \\
(.046)\end{array}$ \\
\hline $\begin{array}{l}\text { Post-BBA } 97 * \text { Restrict } \\
* \text { Predicted High Cost }\end{array}$ & $\begin{array}{c}-.293 * * \\
(.119)\end{array}$ & $\begin{array}{c}-.253 * * \\
(.117)\end{array}$ & $\begin{array}{c}-.588 * * \\
(.161)\end{array}$ & $\begin{array}{c}-.582 * * \\
(.161)\end{array}$ \\
\hline \multicolumn{5}{|l|}{ Personal Characteristics } \\
\hline Male & & $\begin{array}{l}.293 \\
(.700)\end{array}$ & $\begin{array}{c}.301 \\
(.698)\end{array}$ & $\begin{array}{c}.299 \\
(.698)\end{array}$ \\
\hline Married & & $\begin{array}{c}-2.641 * * \\
(.686)\end{array}$ & $\begin{array}{c}-2.597 * * \\
(.684)\end{array}$ & $\begin{array}{c}-2.603 * * \\
(.684)\end{array}$ \\
\hline Male*Married & & $\begin{array}{l}-.382 \\
(.861)\end{array}$ & $\begin{array}{l}-.403 \\
(.857)\end{array}$ & $\begin{array}{l}-.392 \\
(.857)\end{array}$ \\
\hline Predicted Cost & & $\begin{array}{l}.0007^{* *} \\
(.0003)\end{array}$ & $\begin{array}{l}.0008 * * \\
(.0003)\end{array}$ & $\begin{array}{l}.0008 * * \\
(.0003)\end{array}$ \\
\hline Diabetes & & $\begin{array}{c}3.168 * * \\
(.645)\end{array}$ & $\begin{array}{c}3.110^{* *} \\
(.643)\end{array}$ & $\begin{array}{c}3.113^{* *} \\
(.643)\end{array}$ \\
\hline Stroke & & $\begin{array}{c}2.489 * * \\
(.969)\end{array}$ & $\begin{array}{l}2.441^{* *} \\
(.971)\end{array}$ & $\begin{array}{l}2.456^{* * *} \\
(.972)\end{array}$ \\
\hline Alzheimer's & & $\begin{array}{l}-1.993 \\
(2.066)\end{array}$ & $\begin{array}{l}-2.091 \\
(2.079)\end{array}$ & $\begin{array}{l}-2.091 \\
(2.079)\end{array}$ \\
\hline Year fixed effects & Yes & Yes & Yes & Yes \\
\hline State fixed effects & Yes & Yes & Yes & Yes \\
\hline State trends & No & No & Yes & Yes \\
\hline Visits94*Post & No & No & No & Yes \\
\hline Observations & 97,193 & 97,193 & 97,193 & 97,193 \\
\hline
\end{tabular}

Other control variables include year, state, state trends, age group, race, education, income, and other health conditions (amputation of arm or leg, angina pectoris, arthritis, broken hip, cancer, emphysema, hardening of the arteries, hypertension, mental retardation, mental disorders, myocardial infarction, osteoporosis, other heart conditions, paralysis, and Parkinson's disease) and level of difficulty with walking, writing, lifting and kneeling. Regressions that show interactions with high predicted costs also include a control for high predicted costs and interactions of high predicted costs with post-BBA-97 and with Restrict. High predicted cost means predicted costs $>$ \$3877. Equations are estimated using OLS. Standard errors are clustered on state and year. 
Table 5: Medicare Home Health Utilization

\begin{tabular}{|c|c|c|c|c|}
\hline Independent variable & $\begin{array}{c}\text { (1) } \\
\text { Any Medicare } \\
\text { Expenditures }\end{array}$ & $\begin{array}{c}(2) \\
\text { Any Medicare } \\
\text { Expenditures }\end{array}$ & $\begin{array}{c}(3) \\
\text { Medicare } \\
\text { Expenditures }\end{array}$ & $\begin{array}{c}\text { (4) } \\
\text { Medicare } \\
\text { Expenditures }\end{array}$ \\
\hline Post-BBA $97 *$ Restrict & $\begin{array}{c}-.0000004 \\
(.0002)\end{array}$ & $\begin{array}{l}.0004 * * \\
(.0002)\end{array}$ & $\begin{array}{l}-1.89 \\
(1.99)\end{array}$ & $\begin{array}{l}3.22 * * \\
(1.49)\end{array}$ \\
\hline $\begin{array}{l}\text { Post-BBA } 97 * \text { Restrict } \\
* \text { Predicted High Cost }\end{array}$ & & $\begin{array}{c}-.0009 * * \\
(.0003)\end{array}$ & & $\begin{array}{l}-17.67 * * \\
(5.85)\end{array}$ \\
\hline \multicolumn{5}{|l|}{ Personal Characteristics } \\
\hline Male & $\begin{array}{l}.009 * * \\
(.002)\end{array}$ & $\begin{array}{l}.009 * * \\
(.002)\end{array}$ & $\begin{array}{c}27.77 \\
(22.02)\end{array}$ & $\begin{array}{c}28.21 \\
(22.00)\end{array}$ \\
\hline Married & $\begin{array}{l}-.007 * \\
(.003)\end{array}$ & $\begin{array}{c}-.007 * * \\
(.003)\end{array}$ & $\begin{array}{l}-19.91 \\
(28.02)\end{array}$ & $\begin{array}{l}-19.98 \\
(28.00)\end{array}$ \\
\hline Male*Married & $\begin{array}{l}-.002 \\
(.006)\end{array}$ & $\begin{array}{l}-.002 \\
(.006)\end{array}$ & $\begin{array}{l}-30.81 \\
(34.60)\end{array}$ & $\begin{array}{l}-31.18 \\
(34.56)\end{array}$ \\
\hline Predicted Cost & $\begin{array}{l}.000003 \\
(.000003)\end{array}$ & $\begin{array}{l}.000003 \\
(.000003)\end{array}$ & $\begin{array}{l}.01 \\
(.01)\end{array}$ & $\begin{array}{c}.01 \\
(.01)\end{array}$ \\
\hline Diabetes & $\begin{array}{l}.026 * * \\
(.004)\end{array}$ & $\begin{array}{l}.026 * * \\
(.004)\end{array}$ & $\begin{array}{c}294.38 * * \\
(30.85)\end{array}$ & $\begin{array}{c}294.16^{* *} \\
(30.77)\end{array}$ \\
\hline Stroke & $\begin{array}{l}.013 * * \\
(.003)\end{array}$ & $\begin{array}{l}.013 * * \\
(.003)\end{array}$ & $\begin{array}{l}108.27^{* *} \\
(0.79)\end{array}$ & $\begin{array}{c}108.20 * * \\
(40.78)\end{array}$ \\
\hline Alzheimer's & $\begin{array}{c}-.017 * * \\
(.003)\end{array}$ & $\begin{array}{c}-.017 * * \\
(.003)\end{array}$ & $\begin{array}{c}-158.50 * * \\
(65.11)\end{array}$ & $\begin{array}{c}-158.93 * * \\
(65.03)\end{array}$ \\
\hline Observations & 97,142 & 97,142 & 97,193 & 97,193 \\
\hline
\end{tabular}

Other control variables include year, state, state trends, age group, race, education, income, and other health conditions (amputation of arm or leg, angina pectoris, arthritis, broken hip, cancer, emphysema, hardening of the arteries, hypertension, mental retardation, mental disorders, myocardial infarction, osteoporosis, other heart conditions, paralysis, and Parkinson's disease) and level of difficulty with walking, writing, lifting and kneeling. Regressions also control for 1994 state average visits per user interacted with a post-policy dummy variable. Regressions that show interactions with high predicted costs also include a control for high predicted cost as well as an interaction of high predicted cost with post-BBA 97 and with Restrict. High predicted cost means predicted costs $>\$ 3877$. Columns 1 and 2 show marginal effects from Probit models; columns 3 and 4 are estimated using OLS. Standard errors are clustered on state and year. 
Table 6: Beneficiary Utilization of Long-Term Care Facilities

\begin{tabular}{|c|c|c|c|c|c|c|}
\hline Independent variable & $\begin{array}{c}\text { (1) } \\
\text { Any Events }\end{array}$ & $\begin{array}{c}(2) \\
\text { Any Events }\end{array}$ & $\begin{array}{c}(3) \\
\text { Expenditures }\end{array}$ & $\begin{array}{c}(4) \\
\text { Expenditures }\end{array}$ & $\begin{array}{c}(5) \\
\text { Medicare } \\
\text { Expenditures }\end{array}$ & $\begin{array}{c}(6) \\
\text { Medicare } \\
\text { Expenditures }\end{array}$ \\
\hline Post-BBA $97 *$ Restrict & $\begin{array}{l}-.00005 \\
(.00008)\end{array}$ & $\begin{array}{c}.00003 \\
(.00010)\end{array}$ & $\begin{array}{l}.108 \\
(6.67)\end{array}$ & $\begin{array}{l}-1.86 \\
(7.20)\end{array}$ & $\begin{array}{l}-.58 \\
(.43)\end{array}$ & $\begin{array}{c}-.71 * * \\
(.36)\end{array}$ \\
\hline $\begin{array}{l}\text { Post-BBA } 97 * \text { Restrict } \\
* \text { Predicted High Cost }\end{array}$ & & $\begin{array}{l}-.00015 \\
(.00013)\end{array}$ & & $\begin{array}{c}6.66 \\
(18.62)\end{array}$ & & $\begin{array}{c}.38 \\
(1.79)\end{array}$ \\
\hline $\begin{array}{l}\text { Personal Characteristics } \\
\text { Male }\end{array}$ & $\begin{array}{l}.007 * * \\
(.001)\end{array}$ & $\begin{array}{l}.007^{* *} \\
(.001)\end{array}$ & $\begin{array}{l}559.10 * * \\
(163.29)\end{array}$ & $\begin{array}{l}559.01 * * \\
(163.29)\end{array}$ & $\begin{array}{c}17.80 \\
(13.52)\end{array}$ & $\begin{array}{c}17.82 \\
(13.50)\end{array}$ \\
\hline Married & $\begin{array}{c}-.020 * * \\
(.002)\end{array}$ & $\begin{array}{c}-.020 * * \\
(.002)\end{array}$ & $\begin{array}{c}-1330.80 * * \\
(148.22)\end{array}$ & $\begin{array}{c}-1331.01 * * \\
(148.37)\end{array}$ & $\begin{array}{c}1.57 \\
(11.61)\end{array}$ & $\begin{array}{c}1.49 \\
(11.61)\end{array}$ \\
\hline Male*Married & $\begin{array}{l}-.001 \\
(.002)\end{array}$ & $\begin{array}{l}-.002 \\
(.002)\end{array}$ & $\begin{array}{l}202.65 \\
(242.07)\end{array}$ & $\begin{array}{l}203.23 \\
(242.15)\end{array}$ & $\begin{array}{l}-30.04 \\
(22.30)\end{array}$ & $\begin{array}{l}-29.88 \\
(22.28)\end{array}$ \\
\hline Predicted Cost & $\begin{array}{l}.000004 * * \\
(.000001)\end{array}$ & $\begin{array}{l}.000004 * * \\
(.000001)\end{array}$ & $\begin{array}{l}.57 * * \\
(.13)\end{array}$ & $\begin{array}{l}.57 * * \\
(.13)\end{array}$ & $\begin{array}{l}-.008 \\
(.010)\end{array}$ & $\begin{array}{l}-.008 \\
(.010)\end{array}$ \\
\hline Diabetes & $\begin{array}{l}-.001 \\
(.001)\end{array}$ & $\begin{array}{l}-.001 \\
(.001)\end{array}$ & $\begin{array}{c}-611.86^{* *} \\
(144.95)\end{array}$ & $\begin{array}{c}-611.92 * * \\
(145.03)\end{array}$ & $\begin{array}{c}8.97 \\
(10.77)\end{array}$ & $\begin{array}{c}8.92 \\
(10.77)\end{array}$ \\
\hline Stroke & $\begin{array}{l}.008 * * \\
(.002)\end{array}$ & $\begin{array}{l}.008^{* *} \\
(.002)\end{array}$ & $\begin{array}{c}-21.70 \\
(152.77)\end{array}$ & $\begin{array}{c}-21.71 \\
(152.76)\end{array}$ & $\begin{array}{c}16.18 \\
(14.98)\end{array}$ & $\begin{array}{c}16.17 \\
(14.98)\end{array}$ \\
\hline Alzheimer's & $\begin{array}{l}.095 * * \\
(.007)\end{array}$ & $\begin{array}{l}.095^{* *} \\
(.008)\end{array}$ & $\begin{array}{c}7212.61 * * \\
(483.60)\end{array}$ & $\begin{array}{c}7213.72 * * \\
(483.66)\end{array}$ & $\begin{array}{c}15.09 \\
(18.84)\end{array}$ & $\begin{array}{c}15.43 \\
(18.83)\end{array}$ \\
\hline Observations & 97,161 & 97,161 & 97,192 & 97,192 & 97,193 & 97,193 \\
\hline
\end{tabular}

Other control variables include year, state, state trends, age group, race, education, income, and other health conditions (amputation of arm or leg, angina pectoris, arthritis, broken hip, cancer, emphysema, hardening of the arteries, hypertension, mental retardation, mental disorders, myocardial infarction, osteoporosis, other heart conditions, paralysis, and Parkinson's disease) and level of difficulty with walking, writing, lifting and kneeling. Regressions also control for 1994 state average visits per user interacted with a post-policy dummy variable. Regressions that show interactions with high predicted costs also include a control for high predicted cost as well as an interaction of high predicted cost with post-BBA 97 and with Restrict. High predicted cost means predicted costs $>\$ 3877$. Columns 1 and 2 show marginal effects from Probit models; other columns show estimates from OLS. Standard errors are clustered on state and year. 
Table 7: Beneficiary Utilization of Other Types of Care

\begin{tabular}{|c|c|c|c|c|c|c|}
\hline Independent variable & $\begin{array}{c}(1) \\
\text { Inpatient } \\
\text { Expenditures }\end{array}$ & $\begin{array}{c}(2) \\
\text { Inpatient } \\
\text { Expenditures }\end{array}$ & $\begin{array}{c}(3) \\
\text { Outpatient } \\
\text { Expenditures }\end{array}$ & $\begin{array}{c}(4) \\
\text { Outpatient } \\
\text { Expenditures }\end{array}$ & $\begin{array}{c}(5) \\
\text { Medical Provider } \\
\text { Expenditures }\end{array}$ & $\begin{array}{c}\text { (6) } \\
\text { Medical Provider } \\
\text { Expenditures }\end{array}$ \\
\hline Post-BBA 97*Restrict & $\begin{array}{l}-1.76 \\
(7.95)\end{array}$ & $\begin{array}{l}-1.99 \\
(8.04)\end{array}$ & $\begin{array}{l}6.94 * * \\
(2.44)\end{array}$ & $\begin{array}{l}7.38 * * \\
(2.57)\end{array}$ & $\begin{array}{c}.70 \\
(3.17)\end{array}$ & $\begin{array}{c}.37 \\
(3.05)\end{array}$ \\
\hline $\begin{array}{l}\text { Post-BBA } 97 * \text { Restrict } \\
* \text { Predicted High Cost }\end{array}$ & & $\begin{array}{c}.58 \\
(17.41)\end{array}$ & & $\begin{array}{l}-1.53 \\
(4.22)\end{array}$ & & $\begin{array}{l}1.10 \\
(6.37)\end{array}$ \\
\hline \multicolumn{7}{|l|}{ Personal Characteristics } \\
\hline Male & $\begin{array}{l}862.42 * * \\
(105.85)\end{array}$ & $\begin{array}{l}862.52 * * \\
(105.92)\end{array}$ & $\begin{array}{c}115.70 * * \\
(34.92)\end{array}$ & $\begin{array}{c}115.74 * * \\
(34.92)\end{array}$ & $\begin{array}{c}206.93 * * \\
(47.35)\end{array}$ & $\begin{array}{c}206.92 * * \\
(47.36)\end{array}$ \\
\hline Married & $\begin{array}{c}72.25 \\
(135.37)\end{array}$ & $\begin{array}{c}71.90 \\
(135.35)\end{array}$ & $\begin{array}{c}172.54 * * \\
(61.29)\end{array}$ & $\begin{array}{c}172.52 * * \\
(61.28)\end{array}$ & $\begin{array}{c}87.12 \\
(59.50)\end{array}$ & $\begin{array}{c}87.07 \\
(59.50)\end{array}$ \\
\hline Male*Married & $\begin{array}{l}-553.16^{* *} \\
(242.33)\end{array}$ & $\begin{array}{c}-552.50 * * \\
(242.36)\end{array}$ & $\begin{array}{c}-267.13 * * \\
(110.26)\end{array}$ & $\begin{array}{c}-267.13 * * \\
(110.26)\end{array}$ & $\begin{array}{c}-263.12 * * \\
(101.40)\end{array}$ & $\begin{array}{c}-263.00 * * \\
(101.41)\end{array}$ \\
\hline Predicted Cost & $\begin{array}{c}-.24 * * \\
(.12)\end{array}$ & $\begin{array}{c}-.24 * * \\
(.12)\end{array}$ & $\begin{array}{c}-.14 * * \\
(.06)\end{array}$ & $\begin{array}{c}-.14 * * \\
(.06)\end{array}$ & $\begin{array}{c}-.11 * * \\
(.05)\end{array}$ & $\begin{array}{c}-.11 * * \\
(.05)\end{array}$ \\
\hline Diabetes & $\begin{array}{c}1258.63 * * \\
(145.09)\end{array}$ & $\begin{array}{c}1258.43 * * \\
(145.03)\end{array}$ & $\begin{array}{c}433.85 * * \\
(58.55)\end{array}$ & $\begin{array}{c}433.82 * * \\
(58.53)\end{array}$ & $\begin{array}{c}742.41 * * \\
(51.63)\end{array}$ & $\begin{array}{c}742.39 * * \\
(51.63)\end{array}$ \\
\hline Stroke & $\begin{array}{c}733.18 * * \\
(147.74)\end{array}$ & $\begin{array}{c}733.13 * * \\
(147.72)\end{array}$ & $\begin{array}{c}202.39 * * \\
(50.86)\end{array}$ & $\begin{array}{c}202.39 * * \\
(50.86)\end{array}$ & $\begin{array}{c}149.86 * * \\
(64.12)\end{array}$ & $\begin{array}{c}149.86 * * \\
(64.12)\end{array}$ \\
\hline Alzheimer's & $\begin{array}{c}-620.19 * * \\
(154.69)\end{array}$ & $\begin{array}{c}-618.79 * * \\
(154.74)\end{array}$ & $\begin{array}{l}-72.51 * \\
(37.15)\end{array}$ & $\begin{array}{l}-72.48 * \\
(37.16)\end{array}$ & $\begin{array}{c}-274.63 * * \\
(73.42)\end{array}$ & $\begin{array}{c}-274.38 * * \\
(73.38)\end{array}$ \\
\hline Observations & 97,193 & 97,193 & 97,193 & 97,193 & 97,193 & 97,193 \\
\hline
\end{tabular}

Other control variables include year, state, state trends, age group, race, education, income, and other health conditions (amputation of arm or leg, angina pectoris, arthritis, broken hip, cancer, emphysema, hardening of the arteries, hypertension, mental retardation, mental disorders, myocardial infarction, osteoporosis, other heart conditions, paralysis, and Parkinson's disease) and level of difficulty with walking, writing, lifting and kneeling. Regressions also control for 1994 state average visits per user interacted with a post-policy dummy variable. Regressions that show interactions with high predicted costs also include a control for high predicted cost as well as an interaction of high predicted cost with post-BBA 97 and with Restrict. High predicted cost means predicted costs $>\$ 3877$. Equations are estimated using OLS. Standard errors are clustered on state and year. 
Table 8: Total Beneficiary Utilization of Health Care

\begin{tabular}{|c|c|c|c|c|}
\hline Independent variable & $\begin{array}{c}(1) \\
\text { Total } \\
\text { Expenditures }\end{array}$ & $\begin{array}{c}(2) \\
\text { Total } \\
\text { Expenditures }\end{array}$ & $\begin{array}{c}(3) \\
\text { Log Total } \\
\text { Expenditures }\end{array}$ & $\begin{array}{c}(4) \\
\text { Log Total } \\
\text { Expenditures }\end{array}$ \\
\hline Post-BBA 97*Restrict & $\begin{array}{c}3.45 \\
(13.72)\end{array}$ & $\begin{array}{c}7.98 \\
(13.14)\end{array}$ & $\begin{array}{l}.001 \\
(.001)\end{array}$ & $\begin{array}{c}.001 \\
(.001)\end{array}$ \\
\hline $\begin{array}{l}\text { Post-BBA } 97 * \text { Restrict } \\
* \text { Predicted High Cost }\end{array}$ & & $\begin{array}{l}-16.18 \\
(33.88)\end{array}$ & & $\begin{array}{l}-.002 \\
(.002)\end{array}$ \\
\hline $\begin{array}{l}\text { Personal Characteristics } \\
\text { Male }\end{array}$ & $\begin{array}{c}1715.04 * * \\
(249.52)\end{array}$ & $\begin{array}{c}1715.72 * * \\
(249.56)\end{array}$ & $\begin{array}{l}.07 * * \\
(.02)\end{array}$ & $\begin{array}{l}.07 * * \\
(.02)\end{array}$ \\
\hline Married & $\begin{array}{c}-1049.10 * * \\
(303.99)\end{array}$ & $\begin{array}{c}-1049.99 * * \\
(304.12)\end{array}$ & $\begin{array}{c}-.09 * * \\
(.02)\end{array}$ & $\begin{array}{c}-.09 * * \\
(.02)\end{array}$ \\
\hline Male*Married & $\begin{array}{l}-939.27 * \\
(507.37)\end{array}$ & $\begin{array}{l}-938.06^{*} \\
(507.45)\end{array}$ & $\begin{array}{c}-.07 * * \\
(.04)\end{array}$ & $\begin{array}{c}-.07 * * \\
(.04)\end{array}$ \\
\hline Predicted Cost & $\begin{array}{l}.11 \\
(.26)\end{array}$ & $\begin{array}{l}.11 \\
(.26)\end{array}$ & $\begin{array}{l}.000006 \\
(.000019)\end{array}$ & $\begin{array}{l}.000006 \\
(.000019)\end{array}$ \\
\hline Diabetes & $\begin{array}{l}2452.70 * * \\
(285.52)\end{array}$ & $\begin{array}{c}2452.00 * * \\
(285.46)\end{array}$ & $\begin{array}{l}.34 * * \\
(.02)\end{array}$ & $\begin{array}{l}.34 * * \\
(.02)\end{array}$ \\
\hline Stroke & $\begin{array}{c}1398.11^{* *} \\
(291.05)\end{array}$ & $\begin{array}{c}1397.91^{* *} \\
(290.99)\end{array}$ & $\begin{array}{l}.14 * * \\
(.02)\end{array}$ & $\begin{array}{l}.14 * * \\
(.02)\end{array}$ \\
\hline Alzheimer's & $\begin{array}{c}6061.58 * * \\
(511.65)\end{array}$ & $\begin{array}{c}6064.50 * * \\
(511.36)\end{array}$ & $\begin{array}{l}.55 * * \\
(.03)\end{array}$ & $\begin{array}{l}.55^{* *} \\
(.03)\end{array}$ \\
\hline Observations & 97,193 & 97,193 & 94,409 & 94,409 \\
\hline
\end{tabular}

Other control variables include year, state, state trends, age group, race, education, income, and other health conditions (amputation of arm or leg, angina pectoris, arthritis, broken hip, cancer, emphysema, hardening of the arteries, hypertension, mental retardation, mental disorders, myocardial infarction, osteoporosis, other heart conditions, paralysis, and Parkinson's disease) and level of difficulty with walking, writing, lifting and kneeling. Regressions also control for 1994 state average visits per user interacted with a post-policy dummy variable. Regressions that show interactions with high predicted costs also include a control for high predicted cost as well as an interaction of high predicted cost with post-BBA 97 and with Restrict. High predicted cost means predicted costs $>\$ 3877$. Equations are estimated using OLS. Standard errors are clustered on state and year. 
Table 9: Body Mass Index (BMI)

\begin{tabular}{|c|c|c|c|c|c|c|}
\hline Independent variable & $\begin{array}{c}(1) \\
\text { BMI }\end{array}$ & $\begin{array}{c}(2) \\
\mathrm{BMI}\end{array}$ & $\begin{array}{c}(3) \\
\text { Underweight } \\
(\mathrm{BMI}<18.5)\end{array}$ & $\begin{array}{c}(4) \\
\text { Underweight } \\
(\mathrm{BMI}<18.5)\end{array}$ & $\begin{array}{c}(5) \\
\text { Overweight } \\
(\mathrm{BMI}>25)\end{array}$ & $\begin{array}{c}(6) \\
\text { Overweight } \\
(\mathrm{BMI}>25)\end{array}$ \\
\hline Post-BBA 97*Restrict & $\begin{array}{l}-.003 \\
(.005)\end{array}$ & $\begin{array}{l}-.002 \\
(.004)\end{array}$ & $\begin{array}{l}.0001 \\
(.0001)\end{array}$ & $\begin{array}{c}.00006 \\
(.00017)\end{array}$ & $\begin{array}{l}-.0005 \\
(.0003)\end{array}$ & $\begin{array}{l}-.0002 \\
(.0004)\end{array}$ \\
\hline $\begin{array}{l}\text { Post-BBA } 97 * \text { Restrict } \\
* \text { Predicted High Cost }\end{array}$ & & $\begin{array}{l}-.002 \\
(.012)\end{array}$ & & $\begin{array}{c}.00004 \\
(.00029)\end{array}$ & & $\begin{array}{l}-.0013 * \\
(.0007)\end{array}$ \\
\hline \multicolumn{7}{|l|}{ Personal Characteristics } \\
\hline Male & $\begin{array}{c}-.600 * * \\
(.064)\end{array}$ & $\begin{array}{c}-.600 * * \\
(.064)\end{array}$ & $\begin{array}{c}-.009 * * \\
(.002)\end{array}$ & $\begin{array}{c}-.009 * * \\
(.002)\end{array}$ & $\begin{array}{l}.003 \\
(.005)\end{array}$ & $\begin{array}{l}.003 \\
(.005)\end{array}$ \\
\hline Married & $\begin{array}{l}-.134 \\
(.101)\end{array}$ & $\begin{array}{l}-.133 \\
(.101)\end{array}$ & $\begin{array}{l}.004 * * \\
(.002)\end{array}$ & $\begin{array}{l}.004 * * \\
(.002)\end{array}$ & $\begin{array}{c}-.034 * * \\
(.007)\end{array}$ & $\begin{array}{c}-.034 * * \\
(.007)\end{array}$ \\
\hline Male*Married & $\begin{array}{l}.959 * * \\
(.170)\end{array}$ & $\begin{array}{l}.957 * * \\
(.170)\end{array}$ & $\begin{array}{c}-.024 * * \\
(.003)\end{array}$ & $\begin{array}{c}-.024 * * \\
(.003)\end{array}$ & $\begin{array}{l}.117^{* *} \\
(.010)\end{array}$ & $\begin{array}{l}.117^{* *} \\
(.010)\end{array}$ \\
\hline Predicted Cost & $\begin{array}{l}.00001 \\
(.00008)\end{array}$ & $\begin{array}{l}.0000004 \\
(.000085)\end{array}$ & $\begin{array}{c}-.000005 * * \\
(.000001)\end{array}$ & $\begin{array}{c}-.000004 * * \\
(.000001)\end{array}$ & $\begin{array}{l}.000007 \\
(.000005)\end{array}$ & $\begin{array}{l}.000007 \\
(.000005)\end{array}$ \\
\hline Diabetes & $\begin{array}{c}1.482 * * \\
(.086)\end{array}$ & $\begin{array}{c}1.482 * * \\
(.085)\end{array}$ & $\begin{array}{c}-.015 * * \\
(.002)\end{array}$ & $\begin{array}{c}-.015 * * \\
(.002)\end{array}$ & $\begin{array}{c}.119 * * \\
(.006)\end{array}$ & $\begin{array}{c}.119 * * \\
(.006)\end{array}$ \\
\hline Stroke & $\begin{array}{c}-.453 * * \\
(.083)\end{array}$ & $\begin{array}{c}-.453 * * \\
(.083)\end{array}$ & $\begin{array}{l}.007 * * \\
(.002)\end{array}$ & $\begin{array}{c}.007 * * \\
(.002)\end{array}$ & $\begin{array}{c}-.045^{* *} \\
(.007)\end{array}$ & $\begin{array}{c}-.045 * * \\
(.007)\end{array}$ \\
\hline Alzheimer's & $\begin{array}{c}-.401 * * \\
(.121)\end{array}$ & $\begin{array}{c}-.404 * * \\
(.121)\end{array}$ & $\begin{array}{l}.008^{* *} \\
(.003)\end{array}$ & $\begin{array}{c}.008 * * \\
(.003)\end{array}$ & $\begin{array}{c}-.079 * * \\
(.008)\end{array}$ & $\begin{array}{c}-.079 * * \\
(.008)\end{array}$ \\
\hline Observations & 96,007 & 96,007 & 95,953 & 95,953 & 95,998 & 95,998 \\
\hline
\end{tabular}

Other control variables include year, state, state trends, age group, race, education, income, and other health conditions (amputation of arm or leg, angina pectoris, arthritis, broken hip, cancer, emphysema, hardening of the arteries, hypertension, mental retardation, mental disorders, myocardial infarction, osteoporosis, other heart conditions, paralysis, and Parkinson's disease) and level of difficulty with walking, writing, lifting and kneeling. Regressions also control for 1994 state average visits per user interacted with a post-policy dummy variable. Regressions that show interactions with high predicted costs also include a control for high predicted cost as well as an interaction of high predicted cost with post-BBA 97 and with Restrict. High predicted cost means predicted costs $>\$ 3877$. Columns 1 and 2 show estimates from OLS; other columns show marginal effects from Probit models. Standard errors are clustered on state and year. 
Table 10: Functional Limitations

\begin{tabular}{|c|c|c|c|c|c|c|}
\hline Independent variable & $\begin{array}{c}(1) \\
\text { Lots of Difficulty } \\
\text { Stooping }\end{array}$ & $\begin{array}{c}(2) \\
\text { Lots of Difficulty } \\
\text { Stooping }\end{array}$ & $\begin{array}{c}(3) \\
\text { Lots of Difficulty } \\
\text { Lifting }\end{array}$ & $\begin{array}{c}(4) \\
\text { Lots of Difficulty } \\
\text { Lifting }\end{array}$ & $\begin{array}{c}(5) \\
\text { Lots of Difficulty } \\
\text { Walking }\end{array}$ & $\begin{array}{c}(6) \\
\text { Lots of Difficulty } \\
\text { Walking }\end{array}$ \\
\hline Post-BBA 97*Restrict & $\begin{array}{l}.00001 \\
(.0003)\end{array}$ & $\begin{array}{l}.0002 \\
(.0003)\end{array}$ & $\begin{array}{l}-.0001 \\
(.0003)\end{array}$ & $\begin{array}{c}.0002 \\
(.0003)\end{array}$ & $\begin{array}{l}.0003 \\
(.0003)\end{array}$ & $\begin{array}{l}.0005 \\
(.0003)\end{array}$ \\
\hline $\begin{array}{l}\text { Post-BBA } 97 * \text { Restrict } \\
* \text { Predicted High Cost }\end{array}$ & & $\begin{array}{l}-.0006 \\
(.0006)\end{array}$ & & $\begin{array}{l}-.0011 * \\
(.0007)\end{array}$ & & $\begin{array}{l}-.0007 \\
(.0005)\end{array}$ \\
\hline $\begin{array}{l}\text { Personal Characteristics } \\
\text { Male }\end{array}$ & $\begin{array}{c}-.039 * * \\
(.004)\end{array}$ & $\begin{array}{c}-.039 * * \\
(.004)\end{array}$ & $\begin{array}{c}-.049 * * \\
(.003)\end{array}$ & $\begin{array}{c}-.049 * * \\
(.003)\end{array}$ & $\begin{array}{c}-.036 * * \\
(.004)\end{array}$ & $\begin{array}{c}-.036 * * \\
(.004)\end{array}$ \\
\hline Married & $\begin{array}{c}-.041 * * \\
(.005)\end{array}$ & $\begin{array}{c}-.041 * * \\
(.005)\end{array}$ & $\begin{array}{c}-.046 * * \\
(.005)\end{array}$ & $\begin{array}{c}-.046 * * \\
(.005)\end{array}$ & $\begin{array}{c}-.056 * * \\
(.005)\end{array}$ & $\begin{array}{c}-.056 * * \\
(.005)\end{array}$ \\
\hline Male*Married & $\begin{array}{l}.061 * * \\
(.006)\end{array}$ & $\begin{array}{l}.061 * * \\
(.006)\end{array}$ & $\begin{array}{l}.080 * * \\
(.007)\end{array}$ & $\begin{array}{l}.080 * * \\
(.007)\end{array}$ & $\begin{array}{l}.093 * * \\
(.006)\end{array}$ & $\begin{array}{l}.093 * * \\
(.006)\end{array}$ \\
\hline Predicted Cost & $\begin{array}{l}.000028 * * \\
(.000003)\end{array}$ & $\begin{array}{l}.000028^{* *} \\
(.000003)\end{array}$ & $\begin{array}{l}.00004 * * \\
(.000004)\end{array}$ & $\begin{array}{l}.00004 * * \\
(.000004)\end{array}$ & $\begin{array}{l}.000047 * * \\
(.000003)\end{array}$ & $\begin{array}{l}.000047 * * \\
(.000003)\end{array}$ \\
\hline Diabetes & $\begin{array}{l}.029 * * \\
(.005)\end{array}$ & $\begin{array}{l}.029 * * \\
(.005)\end{array}$ & $\begin{array}{l}-.003 \\
(.005)\end{array}$ & $\begin{array}{l}-.003 \\
(.005)\end{array}$ & $\begin{array}{l}.027 * * \\
(.005)\end{array}$ & $\begin{array}{c}.027 * * \\
(.005)\end{array}$ \\
\hline Stroke & $\begin{array}{l}.036^{* *} \\
(.006)\end{array}$ & $\begin{array}{l}.036 * * \\
(.006)\end{array}$ & $\begin{array}{l}.036^{* *} \\
(.005)\end{array}$ & $\begin{array}{l}.036^{* *} \\
(.006)\end{array}$ & $\begin{array}{l}.027 * * \\
(.006)\end{array}$ & $\begin{array}{l}.027 * * \\
(.006)\end{array}$ \\
\hline Alzheimer's & $\begin{array}{l}.118^{* *} \\
(.010)\end{array}$ & $\begin{array}{l}.118 * * \\
(.010)\end{array}$ & $\begin{array}{l}.154^{* *} \\
(.010)\end{array}$ & $\begin{array}{l}.154 * * \\
(.010)\end{array}$ & $\begin{array}{l}.128 * * \\
(.009)\end{array}$ & $\begin{array}{l}.128 * * \\
(.009)\end{array}$ \\
\hline Observations & 97,629 & 97,629 & 97,629 & 97,629 & 97,629 & 97,629 \\
\hline
\end{tabular}

Other control variables include year, state, state trends, age group, race, education, income, and other health conditions (amputation of arm or leg, angina pectoris, arthritis, broken hip, cancer, emphysema, hardening of the arteries, hypertension, mental retardation, mental disorders, myocardial infarction, osteoporosis, other heart conditions, paralysis, and Parkinson's disease). Regressions also control for 1994 state average visits per user interacted with a post-policy dummy variable. Regressions that show interactions with high predicted costs also include a control for high predicted cost as well as an interaction of high predicted cost with post-BBA 97 and with Restrict. High predicted cost means predicted costs $>\$ 3877$. All columns show marginal effects from Probit models. Standard errors are clustered on state and year. 
Table 11: Other Sources of Payment for Home Health Utilization

\begin{tabular}{|c|c|c|c|c|c|c|c|c|}
\hline Independent variable & $\begin{array}{c}(1) \\
\text { Total } \\
\text { Expenditures }\end{array}$ & $\begin{array}{c}(2) \\
\text { Total } \\
\text { Expenditures }\end{array}$ & $\begin{array}{c}(3) \\
\text { Medicare } \\
\text { Expenditures }\end{array}$ & $\begin{array}{c}(4) \\
\text { Medicare } \\
\text { Expenditures }\end{array}$ & $\begin{array}{c}(5) \\
\text { Medicaid } \\
\text { Expenditures }\end{array}$ & $\begin{array}{c}(6) \\
\text { Medicaid } \\
\text { Expenditures }\end{array}$ & $\begin{array}{c}\text { (7) } \\
\text { Out-of-pocket } \\
\text { Expenditures }\end{array}$ & $\begin{array}{c}\quad(8) \\
\text { Out-of-pocket } \\
\text { Expenditures }\end{array}$ \\
\hline Post-BBA $97 *$ Restrict & $\begin{array}{c}-.72 \\
(2.10)\end{array}$ & $\begin{array}{l}3.07 * \\
(1.62)\end{array}$ & $\begin{array}{l}-1.89 \\
(1.99)\end{array}$ & $\begin{array}{l}3.22 * * \\
(1.49)\end{array}$ & $\begin{array}{c}.42 \\
(.35)\end{array}$ & $\begin{array}{c}.46 \\
(.45)\end{array}$ & $\begin{array}{c}.42 \\
(.62)\end{array}$ & $\begin{array}{l}-.67 * \\
(.41)\end{array}$ \\
\hline $\begin{array}{l}\text { Post-BBA } 97 * \text { Restrict } \\
* \text { Predicted High Cost }\end{array}$ & & $\begin{array}{c}-13.09 * * \\
(5.99)\end{array}$ & & $\begin{array}{c}-17.67 * * \\
(5.85)\end{array}$ & & $\begin{array}{c}-.16 \\
(1.09)\end{array}$ & & $\begin{array}{c}3.82 * * \\
(1.59)\end{array}$ \\
\hline \multicolumn{9}{|l|}{ Personal Characteristics } \\
\hline Male & $\begin{array}{c}21.50 \\
(28.80)\end{array}$ & $\begin{array}{c}21.80 \\
(29.26)\end{array}$ & $\begin{array}{c}27.77 \\
(22.02)\end{array}$ & $\begin{array}{c}28.21 \\
(22.00)\end{array}$ & $\begin{array}{l}-10.56 \\
(15.36)\end{array}$ & $\begin{array}{l}-10.55 \\
(15.38)\end{array}$ & $\begin{array}{c}4.53 \\
(7.85)\end{array}$ & $\begin{array}{c}4.40 \\
(7.84)\end{array}$ \\
\hline Married & $\begin{array}{l}-27.62 \\
(52.22)\end{array}$ & $\begin{array}{l}-27.59 \\
(52.21)\end{array}$ & $\begin{array}{l}-19.91 \\
(28.02)\end{array}$ & $\begin{array}{l}-19.98 \\
(28.00)\end{array}$ & $\begin{array}{l}-30.23 \\
(25.16)\end{array}$ & $\begin{array}{l}-30.23 \\
(25.15)\end{array}$ & $\begin{array}{c}26.03 \\
(33.51)\end{array}$ & $\begin{array}{c}26.14 \\
(33.52)\end{array}$ \\
\hline Male*Married & $\begin{array}{l}-28.15 \\
(57.86)\end{array}$ & $\begin{array}{l}-28.58 \\
(57.84)\end{array}$ & $\begin{array}{l}-30.81 \\
(34.60)\end{array}$ & $\begin{array}{l}-31.18 \\
(34.56)\end{array}$ & $\begin{array}{c}37.71 \\
(34.98)\end{array}$ & $\begin{array}{c}37.71 \\
(34.98)\end{array}$ & $\begin{array}{l}-34.82 \\
(27.24)\end{array}$ & $\begin{array}{l}-34.91 \\
(27.25)\end{array}$ \\
\hline Predicted Cost & $\begin{array}{l}.04 * * \\
(.02)\end{array}$ & $\begin{array}{l}.04 * * \\
(.02)\end{array}$ & $\begin{array}{c}.01 \\
(.01)\end{array}$ & $\begin{array}{c}.01 \\
(.01)\end{array}$ & $\begin{array}{c}.02 \\
(.02)\end{array}$ & $\begin{array}{c}.02 \\
(.02)\end{array}$ & $\begin{array}{c}.004 \\
(.004)\end{array}$ & $\begin{array}{c}.004 \\
(.004)\end{array}$ \\
\hline Diabetes & $\begin{array}{c}276.46^{* *} \\
(36.36)\end{array}$ & $\begin{array}{c}276.35 * * \\
(36.30)\end{array}$ & $\begin{array}{c}294.38 * * \\
(30.85)\end{array}$ & $\begin{array}{c}294.16^{* *} \\
(30.77)\end{array}$ & $\begin{array}{c}-19.68 \\
(17.41)\end{array}$ & $\begin{array}{c}-19.68 \\
(17.41)\end{array}$ & $\begin{array}{l}-2.18 \\
(6.36)\end{array}$ & $\begin{array}{l}-2.08 \\
(6.37)\end{array}$ \\
\hline Stroke & $\begin{array}{c}158.79 * * \\
(68.72)\end{array}$ & $\begin{array}{c}158.76^{* *} \\
(68.72)\end{array}$ & $\begin{array}{c}108.27 * * \\
(0.79)\end{array}$ & $\begin{array}{c}108.20 * * \\
(40.78)\end{array}$ & $\begin{array}{l}-34.50 \\
(33.10)\end{array}$ & $\begin{array}{l}-34.50 \\
(33.10)\end{array}$ & $\begin{array}{c}86.03 * * \\
(41.70)\end{array}$ & $\begin{array}{c}86.06 * * \\
(41.71)\end{array}$ \\
\hline Alzheimer's & $\begin{array}{c}-231.72 * * \\
(99.39)\end{array}$ & $\begin{array}{c}-232.38 * * \\
(99.35)\end{array}$ & $\begin{array}{c}-158.50 * * \\
(65.11)\end{array}$ & $\begin{array}{c}-158.93 * * \\
(65.03)\end{array}$ & $\begin{array}{l}-25.87 \\
(29.69)\end{array}$ & $\begin{array}{l}-25.87 \\
(29.70)\end{array}$ & $\begin{array}{l}-31.42 \\
(58.85)\end{array}$ & $\begin{array}{l}-31.69 \\
(58.86)\end{array}$ \\
\hline Observations & 97,193 & 97,193 & 97,193 & 97,193 & 97,193 & 97,193 & 97,193 & 97,193 \\
\hline
\end{tabular}

Other control variables include year, state, state trends, age group, race, education, income, and other health conditions (amputation of arm or leg, angina pectoris, arthritis, broken hip, cancer, emphysema, hardening of the arteries, hypertension, mental retardation, mental disorders, myocardial infarction, osteoporosis, other heart conditions, paralysis, and Parkinson's disease) and level of difficulty with walking, writing, lifting and kneeling. Regressions also control for 1994 state average visits per user interacted with a post-policy dummy variable. Regressions that show interactions with high predicted costs also include a control for high predicted cost as well as an interaction of high predicted cost with post-BBA 97 and with Restrict. High predicted cost means predicted costs $>\$ 3877$. Equations are estimated using OLS. Standard errors are clustered on state and year. 
Table 12: Impact of the IPS, By Income Group

\begin{tabular}{|c|c|c|c|c|c|c|}
\hline \multirow[b]{3}{*}{ Dependent Variable } & \multicolumn{3}{|c|}{ Below the Poverty Line } & \multicolumn{3}{|c|}{ Above the Poverty Line } \\
\hline & (1) & (2) & (3) & (4) & $(5)$ & (6) \\
\hline & Mean & Main effect & Interaction & Mean & Main effect & Interaction \\
\hline Home health visits & $\begin{array}{c}19.21 \\
(78.87)\end{array}$ & $\begin{array}{c}.066 \\
(.095)\end{array}$ & $\begin{array}{c}-.835 * * \\
(.208)\end{array}$ & $\begin{array}{c}10.68 \\
(58.80)\end{array}$ & $\begin{array}{c}.064 \\
(.056)\end{array}$ & $\begin{array}{l}-.412 * \\
(.246)\end{array}$ \\
\hline Total home health expenditures & $\begin{array}{c}567 \\
(2747)\end{array}$ & $\begin{array}{l}5.92 * \\
(3.35)\end{array}$ & $\begin{array}{c}-26.69 * * \\
(6.53)\end{array}$ & $\begin{array}{c}411 \\
(3388)\end{array}$ & $\begin{array}{c}3.03 \\
(2.13)\end{array}$ & $\begin{array}{c}-4.07 \\
(10.09)\end{array}$ \\
\hline Medicare & $\begin{array}{c}543 \\
(2689)\end{array}$ & $\begin{array}{l}5.97 * \\
(3.34)\end{array}$ & $\begin{array}{c}-25.81 * * \\
(6.42)\end{array}$ & $\begin{array}{c}357 \\
(2260)\end{array}$ & $\begin{array}{l}3.19^{*} \\
(1.90)\end{array}$ & $\begin{array}{r}-12.20 \\
(9.67)\end{array}$ \\
\hline Medicaid & $\begin{array}{c}6 \\
(178)\end{array}$ & $\begin{array}{l}-.02 \\
(.14)\end{array}$ & $\begin{array}{l}-.22 \\
(.28)\end{array}$ & $\begin{array}{c}9 \\
(1560)\end{array}$ & $\begin{array}{c}.60 \\
(.58)\end{array}$ & $\begin{array}{c}-.10 \\
(1.78)\end{array}$ \\
\hline Out-of-pocket & $\begin{array}{c}5 \\
(149)\end{array}$ & $\begin{array}{c}.02 \\
(.14)\end{array}$ & $\begin{array}{l}-.72 * \\
(.40)\end{array}$ & $\begin{array}{c}37 \\
(1859)\end{array}$ & $\begin{array}{l}-.82 \\
(.51)\end{array}$ & $\begin{array}{c}6.56 * * \\
(2.58)\end{array}$ \\
\hline Any facility care & $\begin{array}{l}.189 \\
(.391)\end{array}$ & $\begin{array}{c}.0003 \\
(.0005)\end{array}$ & $\begin{array}{c}-.0004 \\
(.0007)\end{array}$ & $\begin{array}{c}.070 \\
(.256)\end{array}$ & $\begin{array}{l}-.00002 \\
(.00009)\end{array}$ & $\begin{array}{l}-.0001 \\
(.0001)\end{array}$ \\
\hline Facility expenditures & $\begin{array}{c}6,018 \\
(19,830)\end{array}$ & $\begin{array}{c}-8.43 \\
(24.55)\end{array}$ & $\begin{array}{c}-13.42 \\
(36.40)\end{array}$ & $\begin{array}{c}1,967 \\
(9,712)\end{array}$ & $\begin{array}{l}-1.79 \\
(4.96)\end{array}$ & $\begin{array}{c}13.80 \\
(18.29)\end{array}$ \\
\hline Inpatient expenditures & $\begin{array}{c}3,185 \\
(10,795)\end{array}$ & $\begin{array}{c}-20.37 \\
(15.35)\end{array}$ & $\begin{array}{l}-15.55 \\
(25.87)\end{array}$ & $\begin{array}{c}2,735 \\
(9,114)\end{array}$ & $\begin{array}{c}3.32 \\
(8.40)\end{array}$ & $\begin{array}{c}16.65 \\
(24.02)\end{array}$ \\
\hline Total expenditures & $\begin{array}{c}13,871 \\
(26,107)\end{array}$ & $\begin{array}{c}-2.44 \\
(34.52)\end{array}$ & $\begin{array}{l}-66.36 \\
(59.38)\end{array}$ & $\begin{array}{c}9324 \\
(18,035)\end{array}$ & $\begin{array}{c}9.03 \\
(12.77)\end{array}$ & $\begin{array}{c}8.73 \\
(39.55)\end{array}$ \\
\hline Difficulty with stooping & $\begin{array}{l}.239 \\
(.426)\end{array}$ & $\begin{array}{c}.0006 \\
(.0006)\end{array}$ & $\begin{array}{c}.0001 \\
(.0010)\end{array}$ & $\begin{array}{c}.146 \\
(.353)\end{array}$ & $\begin{array}{l}.000004 \\
(.00031)\end{array}$ & $\begin{array}{c}-.0019 * * \\
(.0007)\end{array}$ \\
\hline Difficulty with walking & $\begin{array}{c}.317 \\
(.466)\end{array}$ & $\begin{array}{c}.0008 \\
(.0007)\end{array}$ & $\begin{array}{l}-.0003 \\
(.0010)\end{array}$ & $\begin{array}{c}.200 \\
(.400)\end{array}$ & $\begin{array}{c}.0003 \\
(.0003)\end{array}$ & $\begin{array}{c}-.0013 * * \\
(.0006)\end{array}$ \\
\hline Observations & 21,786 & 21,786 & 21,786 & 75,407 & 75,407 & 75,407 \\
\hline
\end{tabular}

Columns 1 and 4 show means of the dependent variable. Columns 2 and 5 show the coefficient on the interaction of a post-BBA97 dummy and the restrictiveness measure. Columns

3 and 5 show the interaction between post-BBA97, the restrictiveness measure, and a predicted high cost dummy. The regression specification is the same as in earlier tables. 


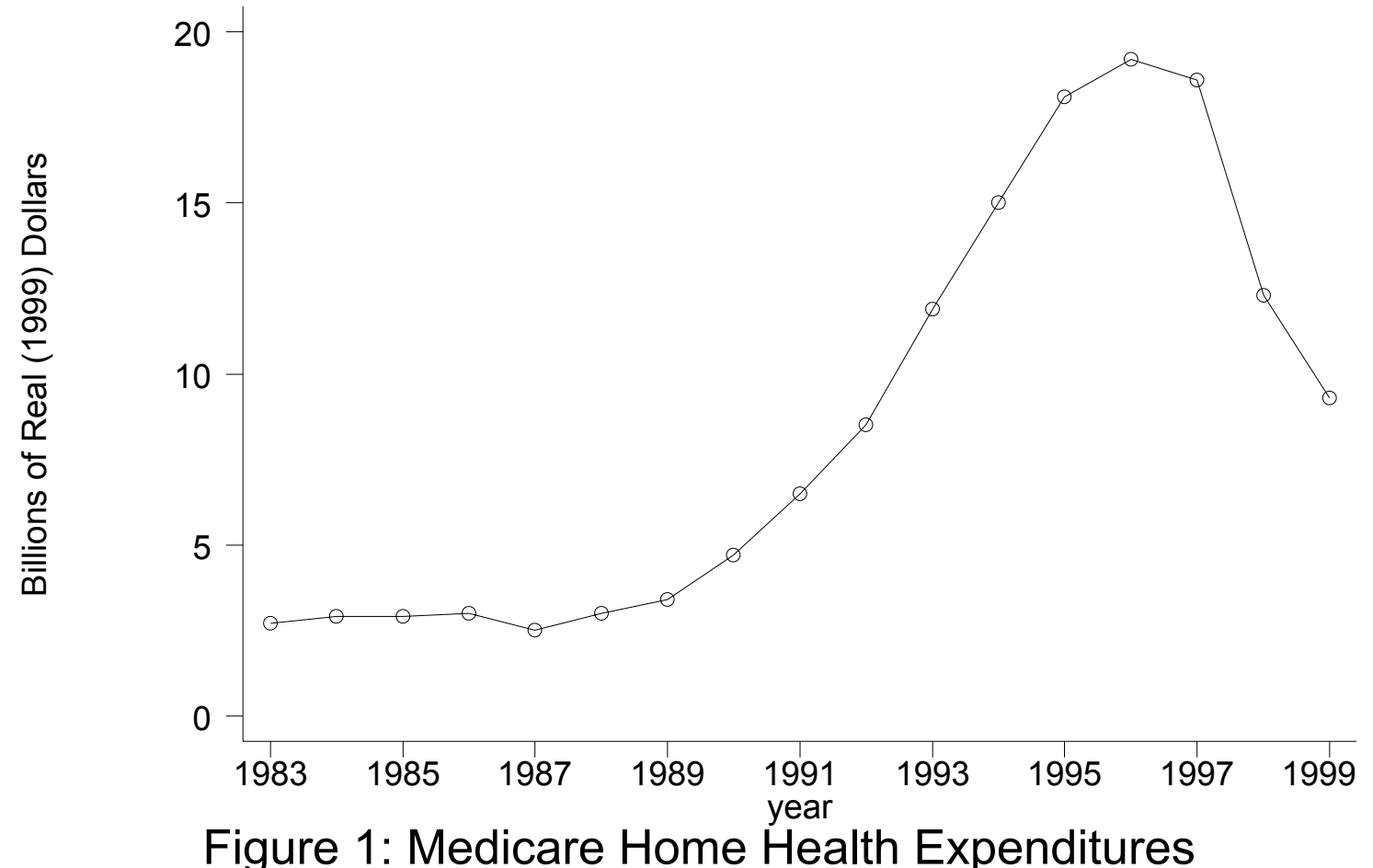

Source: U.S. Congress (2000). 

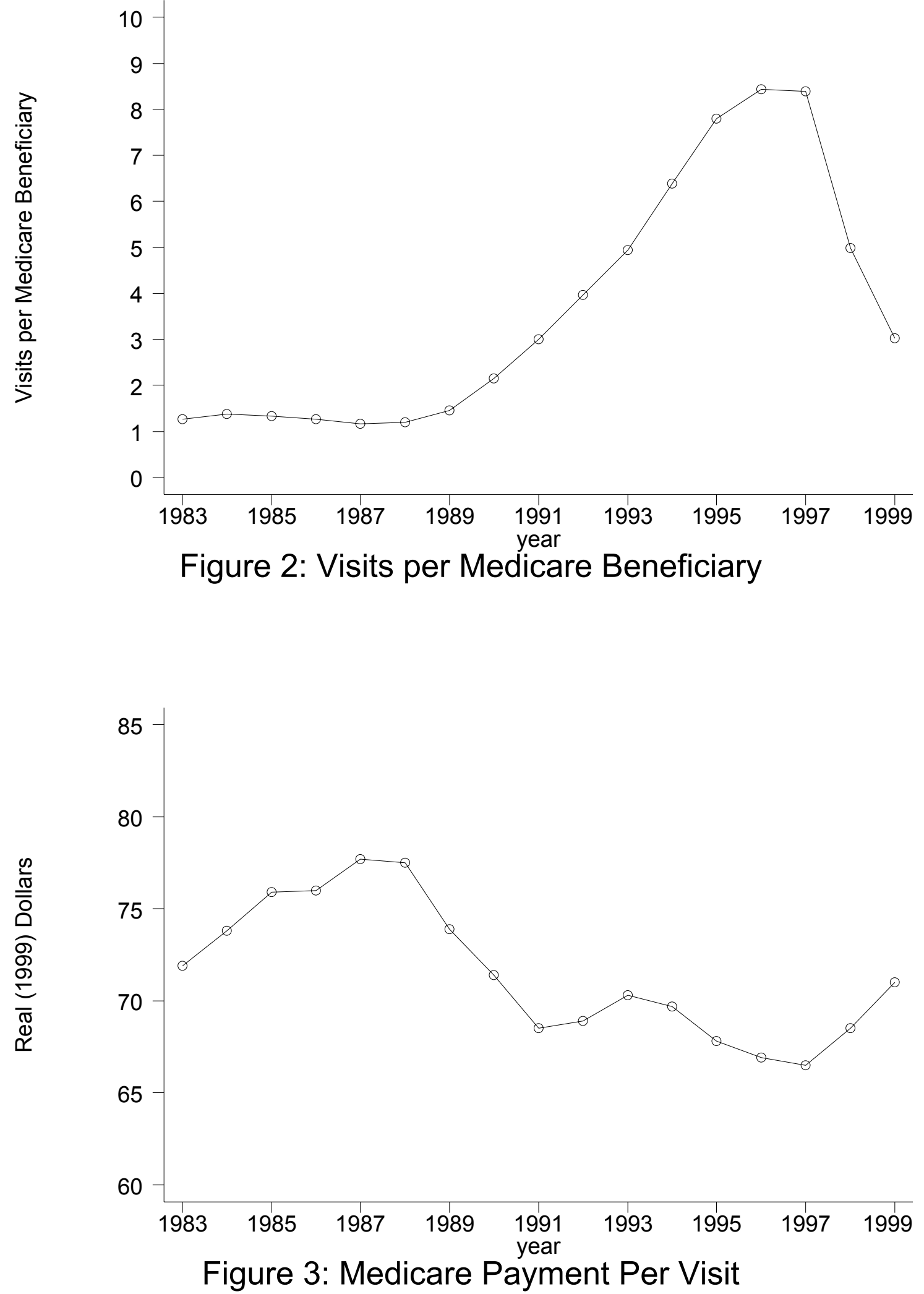

Source: U.S. Congress (2000). 


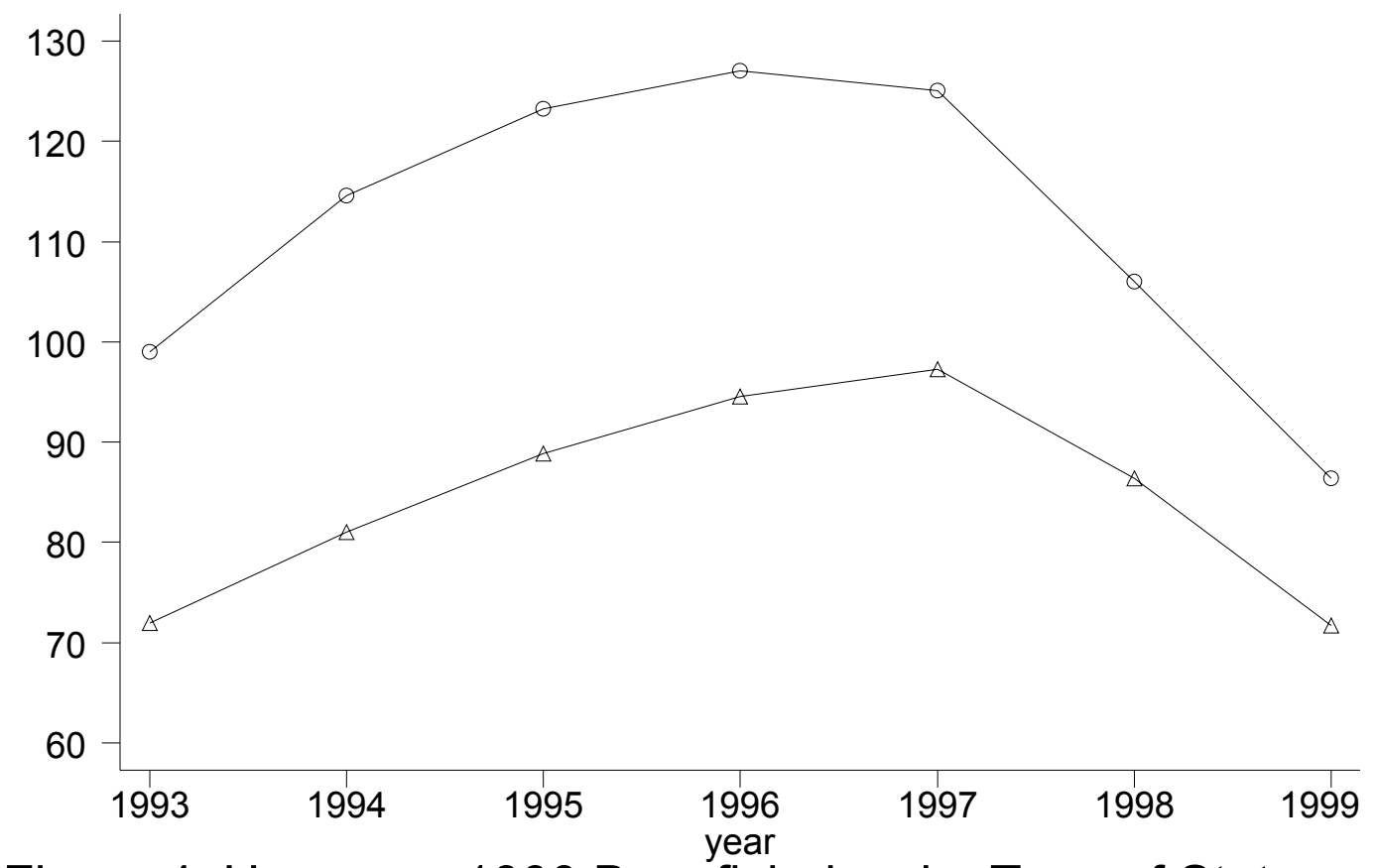

Figure 4: Users per 1000 Beneficiaries, by Type of State

High restrictiveness

Low restrictiveness

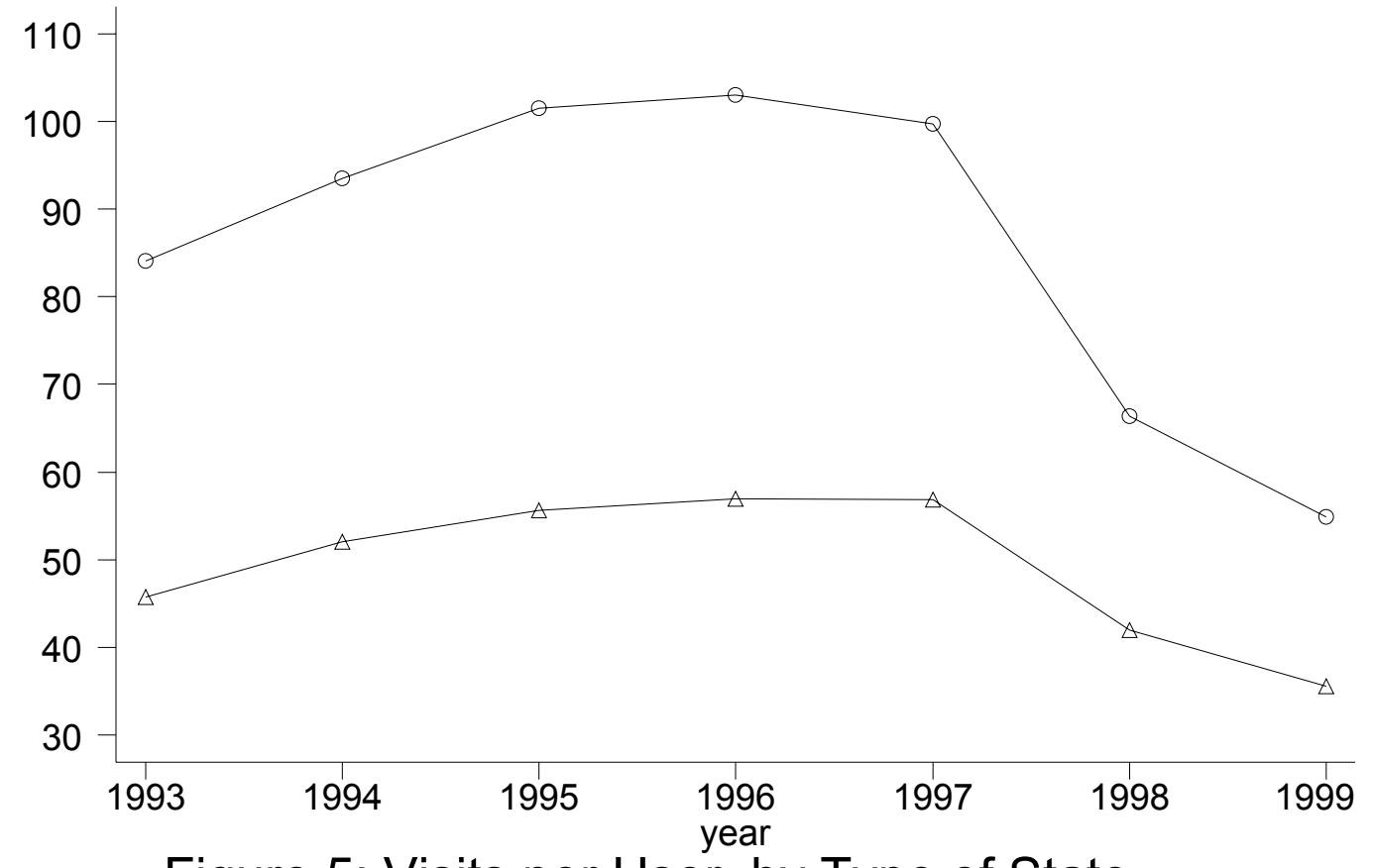

Figure 5: Visits per User, by Type of State

Sources: Health Care Financing Review's annual statistical supplement, GAO (2000), author's calculations. 


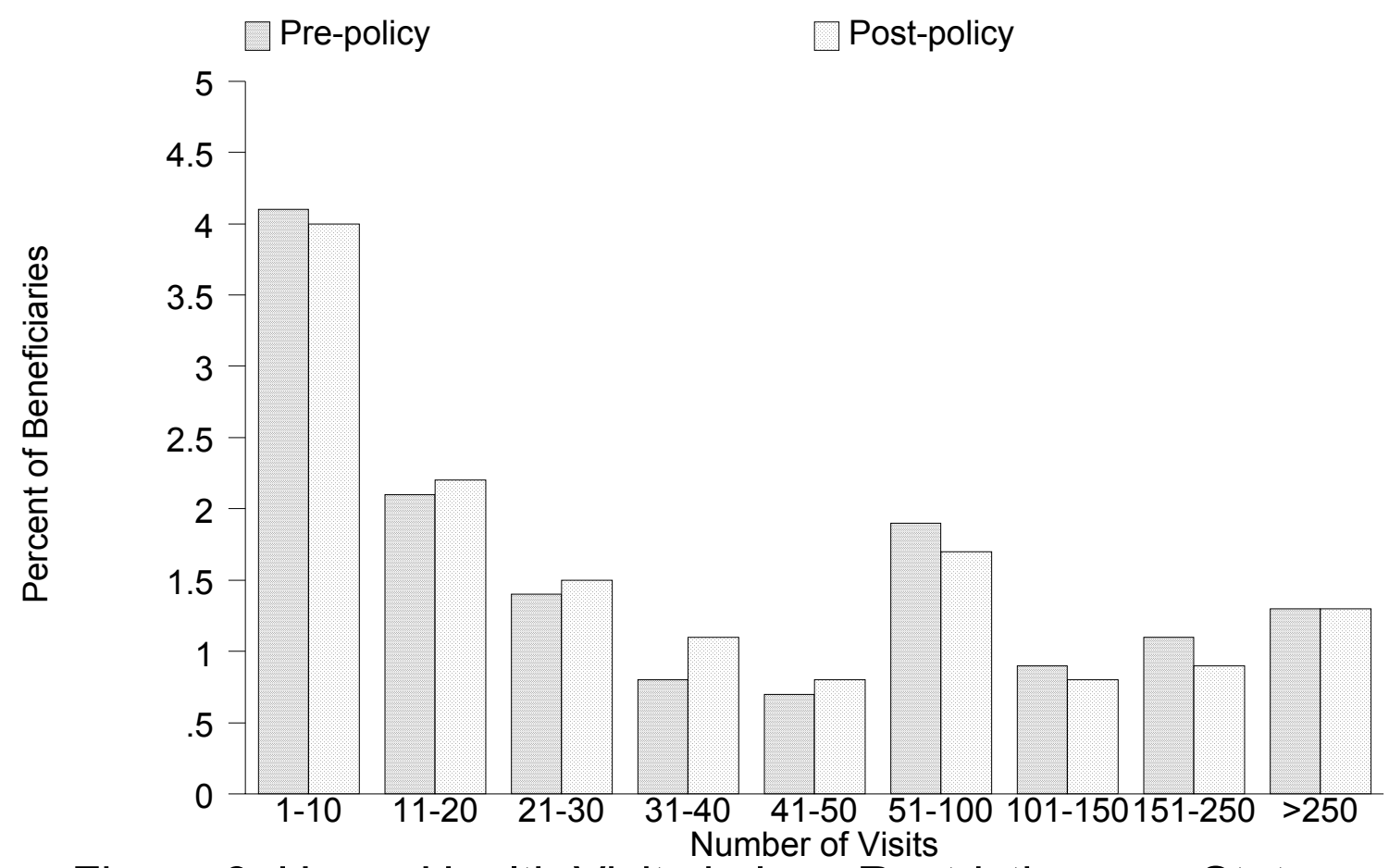

Figure 6: Home Health Visits in Low Restrictiveness States

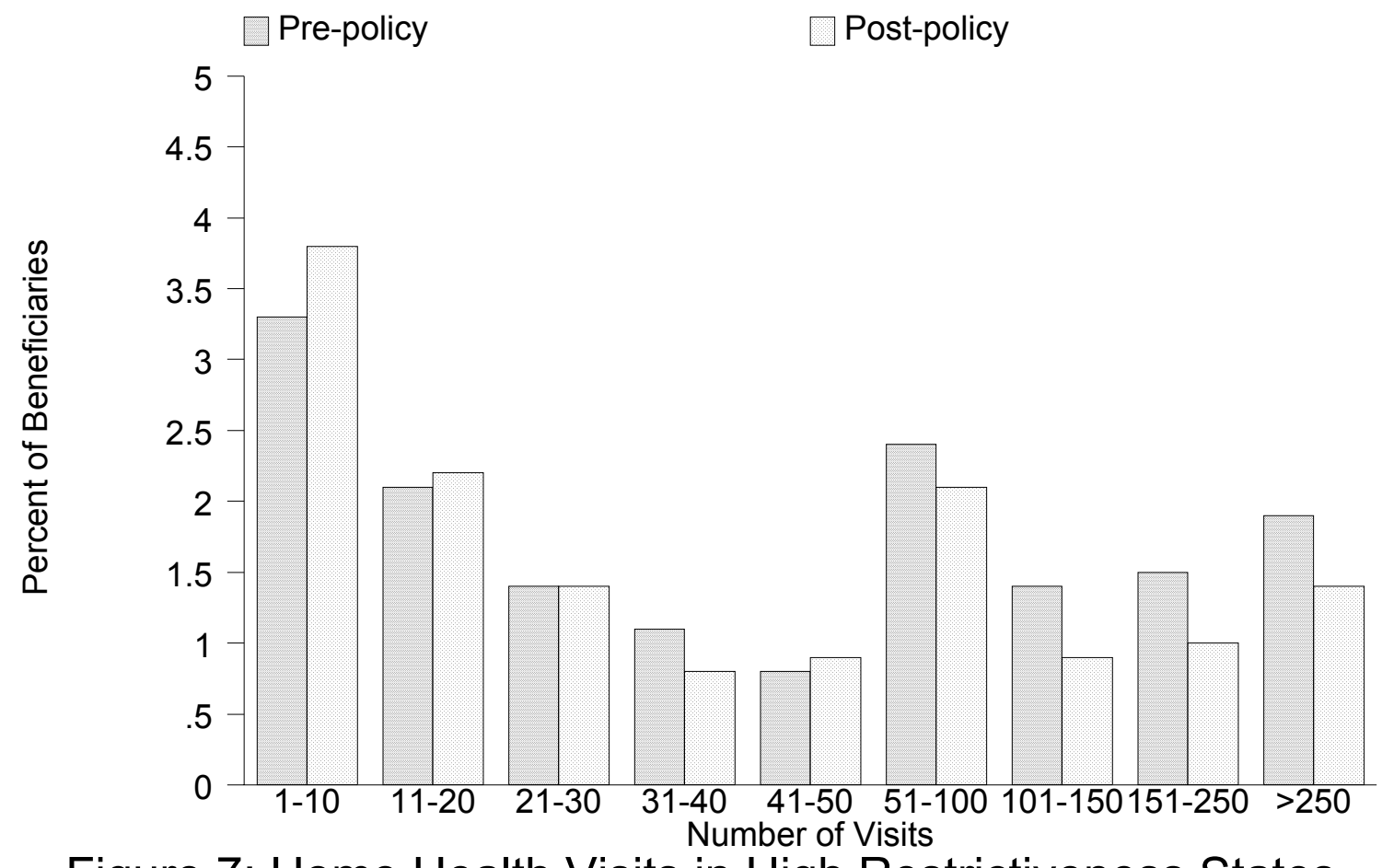

Figure 7: Home Health Visits in High Restrictiveness States

Source: Author's calculations from the MCBS. 